
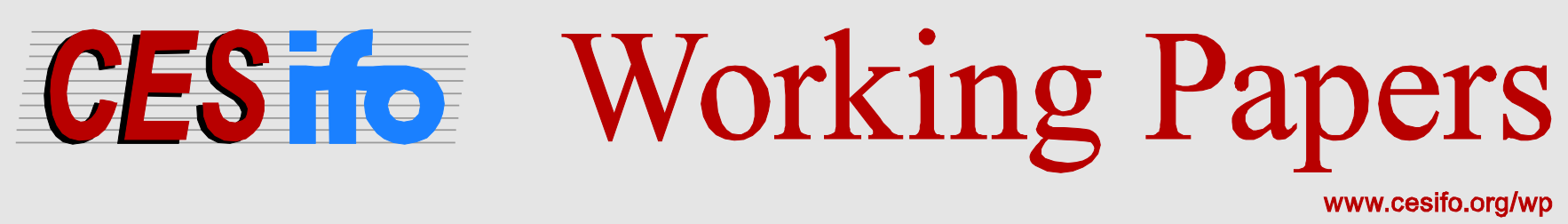

\title{
The Learning Process and Technological Change in Wind Power: Evidence from China’s CDM Wind Projects
}

\author{
Tian Tang \\ David Popp
}

\author{
CESIFO WORKING PAPER No. 4705 \\ CATEGORY 10: ENERGY AND CliMATE ECONOMICS \\ MARCH 2014
}
An electronic version of the paper may be downloaded
- from the SSRN website:
- from the RePEc website: www.SSRN.com
www.RePEc.org
- from the CESifo website:
www.CESifo-group.org/wp

\section{CESifo}




\title{
The Learning Process and Technological Change in Wind Power: Evidence from China’s CDM Wind Projects
}

\begin{abstract}
The Clean Development Mechanism (CDM) is a project-based carbon trade mechanism that subsidizes the users of climate-friendly technologies and encourages technology transfer. The CDM has provided financial support for a large share of Chinese wind projects since 2002. Using pooled cross-sectional data of 486 registered CDM wind projects in China from 2002 to 2009, we examine the determinants of technological change in wind power from a learning perspective. We estimate the effects of different channels of learning-learning through R\&D in wind turbine manufacturing, learning from previous experience of installation, and learning through the network interaction between project developer and turbine manufacturer-on technological change, measured as reductions in projected costs or as increased capacity factor across CDM wind projects. While we find that a manufacturer's R\&D and previous installation experience matter, interactions between wind turbine manufacturers and wind project developer lead to the largest cost reductions. Whereas existing literature suggests that wind power firms can learn from the experience of other wind farm developers, our results indicate that wind power firms mainly learn from their own experience and that knowledge spillovers mostly occur within certain partnerships between wind project developer and foreign turbine manufacturers in China's wind power industry.
\end{abstract}

JEL-Code: O330, O380, Q420, Q480, Q540, Q550.

Keywords: climate change, Clean Development Mechanism, technological change, technology transfer, collaboration, learning curves, patents.

\author{
Tian Tang* \\ The Maxwell School \\ Syracuse University \\ 426 Eggers Hall \\ USA - Syracuse, NY 13244-1020 \\ ttang01@syr.edu
}

\author{
David Popp \\ The Maxwell School \\ Syracuse University \\ 426 Eggers Hall \\ USA - Syracuse, NY 13244-1020 \\ dcpopp@maxwell.syr.edu
}

*corresponding author

February 4, 2014

This work was supported by DOE grant \#DE-SC0005171. We thank Kelly Sims Gallagher, Xiaomei Tan, and seminar participants at Syracuse University and the Association for Public Policy and Management's Fall Research Conference and Conference on Collaboration among Government, Market, and Society: Forging Partnerships and Encouraging Competition for helpful comments on earlier versions of this paper. 


\section{Introduction}

As the world's largest energy consumer and carbon dioxide $\left(\mathrm{CO}_{2}\right)$ emitter, China's energy consumption and carbon emissions are a focus of global climate change and energy security talks. Because China has abundant wind resources with great development potential, increasing the share of wind in China's energy mix is a promising solution (Wang, 2010). China's wind industry has

developed rapidly during the past ten years. After experiencing annual growth rates of wind installed capacity over 100\% from 2003 to 2009, China became the worlds' largest wind power country in terms of cumulative installed capacity in 2010 (GWEC, 2012). As a result of this massive wind capacity expansion, China has also developed a domestic wind power equipment supply chain. China's three largest domestic wind turbine manufacturers were ranked among the top ten wind turbine manufacturers in the world by 2010 (Wang et al., 2012). This immense progress is driven by a variety of policy instruments that the Chinese government has implemented to incentivize investment in wind energy, including domestic policies and international support.

Perhaps the most notable international support program for the development of renewable energy in China is the Clean Development Mechanism (CDM). The CDM is an international carbon trade mechanism under the Kyoto Protocol that assists developed countries to fulfill their committed emission reductions through financing projects that can reduce carbon emissions in developing countries. A secondary goal of the CDM is to help developing countries achieve sustainable development. The transfer of climate-friendly technologies from developed countries to recipient countries can help with the goal of achieving sustainable development, particularly if the technologies transferred lead to knowledge spillovers that reduce the future costs of emissions reductions within the country (Popp, 2011). In this paper, we use data on CDM wind projects in China to assess the impact of technology transfer and learning on renewable energy costs in the 
country. We ask whether expected project costs fall after other similar projects in the country. Moreover, we consider whether costs fall throughout the country or just locally. More localized effects suggest spillovers, whereas project costs falling throughout the country (and perhaps across the world as well) suggest other types of technological changes at work, such as the development of more efficient turbines by leading global manufacturers. In addition, we also test the effects of different learning channels, such as R\&D in wind turbine manufacturing, previous installation experience, and collaboration between turbine manufacturers and project developers, on technological change.

Our study contributes to both the CDM and technological learning literature. Existing studies examining CDM's efficacy on transfer of renewable energy technologies and the subsequent diffusion of these technologies in developing countries are mostly qualitative and descriptive. These papers argue that the CDM has promoted the development of renewable energy in developing countries, but the impacts vary across technologies and countries (Lewis, 2010; Schneider, 2008; Schneider et al., 2010; Wang, 2010). While some empirical studies analyze the determinants of technology transfer via CDM projects (Seres, 2007\& 2009; Dechezlepretre, 2008\& 2009; Hascic \& Johhnstone, 2011; Schindm, 2011), empirical evidence on the effectiveness of technology transfer and the diffusion of the technologies - the technological progress induced by CDM projects—is inadequate. Using CDM wind projects in China as our sample, we attempt to fill this intellectual gap by providing empirical evidence on technological progress in China's CDM wind projects, and on the learning channels that have led to this technological progress.

Our paper adds to the learning literature by incorporating collaboration theories to explain the learning process and providing evidence for a learning-by-interacting effect. The detailed data in CDM project design documents (PDD) allows us to study the relationship among various actors 
in the development of China's wind industry, including project developers and turbine manufacturers. Built on the existing literature that tests learning-by-doing and learning-bysearching effects (Junginger et al., 2005; Taylor et al., 2006; Nemet, 2006 \& 2012; Soderholm \& Klassen, 2007; Soderholm \& Sundqvist, 2007; Qiu and Anadon, 2012; Patridge, 2013), we show that the collaborations between project developers and turbine manufacturers are important sources of learning that takes place in the Chinese wind industry. In addition, our paper provides one of the first empirical studies of learning in the Chinese wind industry.

Our research has policy implications for international climate policy makers and the Chinese government. Studying one of the world's largest wind power producers in which most of the wind projects are supported by CDM, our research sheds light on how CDM, as a demand-side policy subsidizing the adoption of wind technologies, can be used to facilitate technological change in wind power. Although the evidence of knowledge spillovers is not apparent, the learning-by-doing effect itself still provides justification for demand-side subsidies to price negative externalities and stimulate demand in order to provide opportunities for learning-bydoing. Moreover, the evidence of learning-by-interacting effect between foreign turbine manufacturers and local wind farm developers indicates that the financial support from CDM could also result in technological progress in developing countries through increasing the opportunities of technology transfer. By focusing on the roles of various actors in the wind industry, our research increases the understanding of the learning process in China's wind industry and helps the Chinese government better target policies to facilitate different channels of learning, especially learning through the collaboration between wind farm developers and turbine manufacturers.

We proceed with a review of previous work on policy tools and technological change in China's wind power, including a discussion of the important roles of CDM in the development of 
China's wind industry, and the standardized CDM project process. Section 3 provides the theoretical framework for learning process in wind projects and presents our hypotheses. Section 4 discusses the data and empirical models that we use to test the effects of different channels of learning. Section 5 and section 6 analyze the empirical results and summarizes our main conclusions respectively.

\section{The CDM and the Development of China's Wind Industry}

\subsection{Policy instruments and technological change in China's wind industry}

There are two market failures in the innovation and adoption of renewable energy technologies - the non-priced environmental damages caused by fossil fuel energy and the underinvestment in new technologies due to knowledge spillovers. For the wind industry, wind power is currently less cost-competitive than electricity generated from coal and natural gas because the negative externalities of fossil fuel power are not included in energy prices. Moreover, private firms do not consider the potential social benefits from knowledge spillovers when investing in wind technology, leading to underinvestment.

Due to these market failures, policy tools are often used to induce technological change in wind energy. The Chinese government has implemented a bundle of domestic policies to facilitate wind power deployment and to promote domestic wind technology advancement, such as the national wind concession program, mandating that a share of electricity be generated from renewable energy, tax relief for wind farms, a power surcharge for renewables, and R\&D subsidies. Moreover, the Chinese government has also actively engaged in international collaboration to foster international technology transfer and redirect domestic investment in wind technology (Zhang et al., 2009; Lewis, 2010). As shown in Table 1, these policy instruments can be further classified as supply-side policies that subsidize the wind technology R\&D activities and demand- 
side policies that subsidize the demand for wind technologies. CDM is an international financial support that subsidies the users of wind technologies.

[Table 1]

Previous studies on the relationship between policy instruments and the technological achievement in China's wind industry are mainly qualitative and descriptive. They systematically reviewed policies that support wind industry, and then described the technological change in terms of the upgrading of wind turbine size, increased innovation and patenting activities of domestic turbine manufacturers, and cost reduction in turbine manufacturing and electricity generation (Zhang et al., 2009; Wang, 2010; Ru et al., 2012; Huang et al., 2012; Wang et al., 2012; Lewis, 2013). Although some scholars studied how the policy support induced the technological progress in wind turbine manufacturing industry ( $\mathrm{Ru}$ et al., 2012; Lewis, 2013), most descriptive and qualitative research did not analyze the link between policy instruments and the technological change.

Empirical research explaining technological change in China's wind power is rare. Using wind projects from China’s national concession programs ${ }^{1}$ from 2003 to 2007, Qiu and Anadon (2012) applied the learning curve model to examine the factors influencing the price of wind power measured by the bidding price of each bidder participating in the national concession programs. They found that the joint-learning from technology adoption and wind projects installation experience, localization of wind turbine manufacturing, and wind farm economies of scale significantly affect the price of wind power. However, their sample only included 15 wind projects,

\footnotetext{
${ }^{1}$ Prior to 2009, any wind project in China with capacities over $50 \mathrm{MW}$ would go through a national concession bidding process managed by the central government to select its developer. Potential developers were invited to join this public bidding process. The bidder who offered the "best price" under the terms provided by the bidding method would win the right to build the wind farm and sell the electricity at its bidding price to the grid. From 2003 to 2008 , five rounds of national concession bidding programs produced 18 wind projects (Zhang et al., 2009; Wang et al., 2012; Qiu et al., 2012).
} 
which accounts for less than $50 \%$ of the total installed capacity nationwide during the observing period. In addition to its small sample, the bidding price they use may underestimate the production cost of wind power. Large players, such as big state-owned developers that are not driven by a profit-maximization objective, could commit to below cost prices in order to win the contract first (Yang et al, 2010; Wang, 2010). The estimated internal rate of return (IRR) in those proposals were often below the industrial benchmark (Li et al., 2008). ${ }^{2}$

In this paper, we use data from CDM wind projects in China to explain technological change in China's wind power. This data provides a more representative sample and less distorted production cost of wind power, as described in more detail below. Moreover, our empirical analysis on CDM wind projects sheds light on how international support, such as CDM, leads to technological progress in wind power, which is often neglected in previous qualitative and descriptive research.

\subsection{CDM as a demand-side policy for wind technology}

As a demand-side policy that subsidizes the users of wind technology, CDM has, to a great extent, facilitated the adoption of wind technology in China since 2002. As shown in Figure 1, the annual incremental installed capacity from wind projects registered as CDM projects contributes to a large share of the annual incremental installed capacity in China. From 2003 to 2009, the total installed capacity from CDM wind projects account for $74.7 \%$ of the total installed capacity in China. To incentivize investment in wind, the Chinese government encouraged and even acted as a broker to engage wind farm developers in CDM project application. During the project design stage, local government agencies in charge of approving wind farm development proposals would recommend CDM to some proposed projects with IRR below the industrial benchmark in order to

\footnotetext{
${ }^{2}$ According to the State Power Corporation's “Interim Rules on Economic Assessment of Electrical Engineering Retrofit Projects", the benchmark IRR for a project in power industry is $8 \%$ of the total investment.
} 
overcome their financial obstacles. At the national level, industrial associations such as the Chinese Renewable Energy Industries Association, which manage the industry on behalf of the government, hold workshops to help renewable energy project developers learn CDM rules and process (Lin et al., 2004).

[Figure 1]

In addition to increasing wind power deployment, CDM has also improved wind project operation and management by helping China's wind industry to learn about advanced wind technologies and scientific monitoring mechanisms. One approximate measurement for wind technology progress that has been used in many previous studies is the size of wind turbines $(\mathrm{Ru}$ et al., 2012; Wang et al., 2012). In our sample, the average size of the wind turbines used in CDM projects increased from 0.90 MW in 2002 to $1.45 \mathrm{MW}$ in 2009. As further evidence of the development of China's domestic wind industry, note that, since 2006, the majority of installed capacity in CDM projects are turbines produced by Chinese wind turbine manufacturers.

\subsection{The standardized CDM project process and the validity of project documents}

All CDM wind projects are registered and managed in a highly standardized and transparent process according to the CDM legal framework under the Kyoto Protocol. The key criteria for CDM project approval is whether a project demonstrates its "additionality", which means that the proposed wind project could not be developed without the revenue from CDM carbon trading due to high financial risk or technical barriers. If a project cannot demonstrate the additionality by using methods provided by CDM rules, its application will be rejected. Once the CDM executive board (EB) approves a wind project for CDM registration, the project can get emission credits, known as certified emission reductions (CERs), based on its annual electricity generation. The project developer can sell these CERs to emission credit buyers from developed 
countries and use this revenue to subsidize its investment. On average, the economic incentive from CDM revenue is about 0.05 to $0.1 \mathrm{RMB} / \mathrm{kWh}$, which approximately equals $10 \%-20 \%$ of the electricity price of wind power (Lewis, 2010 \& 2013; Li, 2010; Zhang et al, 2009).

A typical CDM wind project cycle has six steps, as shown in Figure 2. First, a wind project developer prepares and submits a standardized PDD and supporting materials, including a financial analysis. The PDD and supporting materials must be validated by a third party auditing agency (i.e. the designated operational entity, or DOE) accredited by the EB according to check whether the proposed project meets the CDM requirements before it can register as a CDM project. During its operational phase, carbon emission reductions from the project activity are monitored and verified by another third party agency according to methods specified in the validated PDD. The EB issues CERs to the project developer based on the verification.

[Figure 2]

These independent and transparent auditing and monitoring procedures ensure the validity of the CDM PDDs. For all projects reaching the registration step, their PDD and supporting financial analysis are available on the CDM official website for public comments before registration. In addition, the validation and monitoring reports are also available on the CDM website to provide a record of the complete process.

\section{Theoretical Framework and Hypotheses}

The CDM has subsidized the majority of China’s wind projects and has facilitated the technological change of China's wind industry during the past ten years. We use CDM wind projects in China to analyze the learning process in China's wind industry and to examine the effects of different channels of learning on technological change. We measure technological change as the reduction of electricity production cost across different wind projects. The learning 
process in our study refers to how knowledge related to wind power is acquired and diffused among different participants in the wind projects, including project developers and wind turbine manufacturers. In China, power generation and power transmission are separated. Wind project developers are power companies in charge of power generation, which are either state-owned enterprises or private power companies. Project developers purchase wind turbines from either domestic or foreign wind turbine manufacturers, who work closely with project developers.

Following the technological learning and collaboration theories, we identify the following channels of learning that could lead reduced electricity production costs.

\subsection{Learning by doing (LBD)}

The traditional learning curve model explains increased productivity, typically measured through reduced production costs, as a function of learning from the accumulation of experience in production (Arrow, 1962). Experience curves have been widely used to model the cost reduction of renewable technologies, such as solar photovoltaics, wind turbine manufacturing, and wind power production (Grubler et al., 1999; Ibenholt, 2002; Junginger et al., 2005; Nemet, 2006 \& 2012; Qiu and Anadon, 2012; Patridge, 2013).

In wind power, the unit cost of electricity production could be reduced through the accumulation of experience in wind turbine manufacturing and installation, and/or through the accumulation of experience in wind project development and operation. As the wind turbine manufacturer's experience in turbine production and installation increases over time, the cost of manufacturing a wind turbine and installing a wind turbine may decrease. Similarly, experience of developing and operating wind projects helps project developers learn more about choosing a quality site, selecting a suitable wind turbine and operating the wind farm efficiently. Such experience will result in lower costs for wind power. Thus, the first two hypotheses we test are: 


\section{$H_{1}:$ The more experience the CDM project developer has developing and operating wind}

projects, the lower the unit production costs of the current project will be.

$\mathrm{H}_{2}$ : The greater the production and installation experience of a project's wind turbine manufacturer, the lower the unit production costs of the current CDM project will be.

\subsection{Knowledge spillover effects}

Within the learning-by-doing literature, a subset of papers identify knowledge spillover effects. These papers find that firms can learn from a competitor firm's experience, but that internal experience has a larger effect (Thornton and Thompson, 2001). Once a new technology has been commercialized, its use is hard to hide from rival firms. Thus, wind power companies can also learn how to develop and operate a wind farm from the experience of other developer's wind projects (Nemet, 2012; Qiu and Anadon, 2012). To test both the existence and appropriability of learning-by-doing, Nemet (2012) uses a panel data of wind projects in California. He estimates the learning effects on wind farm installation and operation from internal experience at both the project and firm level, and from external experience both within the state of California and in the global wind market. The results indicate that wind farm developers learn from their own projects and from the experience of other firms in both installation and operation. Such external spillovers justify policies that subsidize the demand for wind technology. Similarly, Qiu and Anadon's work (2012) on the wind industry in China also shows learning from industrial experience, but it is not clear that the Chinese wind developers learn from their own experience. As they point out, the details of all bids were made public every year, providing a source for other developers to learn. For CDM projects, the transparent project registration and monitoring process allows information sharing on project design and operation among project developers, which may particularly facilitate the knowledge spillovers across CDM projects. Therefore, we also test: 
$H_{3}$ : Increased experience developing and operating wind projects by other firms in the industry also leads to lower unit production costs for the current CDM project.

\subsection{Learning by searching (LBS)}

Wind technology innovation through research, development and demonstration (RD\&D), often referred to as "learning-by-searching" (LBS), can also lead to wind power cost reductions (Junginger et al, 2005; Kahouli-Brahmi, 2008; Qiu and Anadon, 2012). Examples of technological improvements through RD\&D include larger turbines, lighter materials, more efficient turbine design and improved control systems, which could either reduce the cost of a wind turbine or increase the efficiency of converting wind energy to electricity. Extending traditional one-factor learning curve models to include R\&D, several recent studies use two-factor learning models to disentangle the impacts of $R \& D$ and cumulative experience on technological change in wind power (Soderholm \& Klassen, 2007; Soderholm \& Sundqvist, 2007; Qiu and Anadon, 2012). While the empirical studies of the European wind power sector suggest that R\&D is the dominant factor, Qiu and Anadon's research, which covers just a five year period, does not successfully separate the effect of LBS and LBD due to the multicollinearity between their LBD and LBS variables. We use a manufacturer-specific stock of knowledge, described in section 4, to identify and test the learning-by-searching effect:

$H_{4}:$ The greater the knowledge stock that a wind turbine manufacturer has accumulated through its R\&D, the lower the unit production cost of the CDM project using its turbines will be.

\subsection{Learning by interacting (LBI)}

The literature on technological learning also discusses another channel of learning learning by interacting (LBI). Improving network interactions between research institutes, 
manufacturers and end-users allows for better diffusion of knowledge (Grubler, 1998; Junginger et al, 2005). Collaborative and long-term partnerships increase the likelihood of tacit knowledge transfer by increasing trust between the two parties and reducing information asymmetry (Schneider, 2008). Similarly, interagency collaboration facilitates resource and knowledge sharing among network partners. In inter-firm networks, firms can have some degrees of access to the specialized knowledge of their partners while exploiting and enhancing the existing knowledge and capacities within themselves (Cohen and Levinthal 1990; Inkpen and Beamish 1997). The trust that network partners have between each other is found to be instrumental in reducing transaction costs, improving investments and stability in relations, and stimulating learning, knowledge sharing, and innovation (Koppenjan and Klijin, 2004). Previous cooperative ties between the network partners are positively associated with the development of inter-firm trust (Inkpen \& Currall 2004).

In a wind project, the project developer works with its turbine supplier in many stages, such as turbine installation, operation and maintenance. Thus, another important channel of technological learning in wind projects could be the joint learning between project developer and wind turbine manufacturer on installation and operation through their collaboration in one or multiple wind projects. According to the CDM PDDs we have examined, frequent communication and training activities regarding operation and maintenance between turbine suppliers and project developers contributes to the absorption and dissemination of wind technologies, particularly the advanced technologies embedded in the imported turbines. Therefore, we test the learning-byinteracting effect separately:

$H_{5:}$ The more cooperation that the developer has with the same manufacturer prior to the current CDM project, the lower the unit production cost of this project will be. 


\section{Data and Descriptive Statistics}

To examine the effects that different learning channels have on electricity production costs across wind projects, we use pooled cross-sectional data of 510 registered CDM wind projects in China that started construction from 2002 to 2009. After we exclude the observations that have missing data for some variables, the sample that we use for empirical analysis has 486 projects. These projects were developed by 87 developers and used wind turbines from 23 turbine manufacturers. Therefore, many developers and turbine manufactures participated in more than one CDM wind project in China. A developer may have cooperated with the same wind turbine manufacturer in several projects.

We combine several datasets for this study. The CDM project data, including information on project costs, project size, turbine size, annual electricity production, project developer, and turbine manufacturers, is collected from the validated CDM PDDs and their financial analyses. ${ }^{3}$ Data on provincial level and manufacturer's installed capacity comes from the Chinese Wind Energy Association's annual reports. Although there are some wind projects not included in the CDM database, non-CDM installed capacity only accounts for a small share of the total installed capacity in China. ${ }^{4}$ The patent data for knowledge stock calculation is obtained from the Delphion database.

\subsection{Key variables}

\subsection{Dependent variables}

We use several dependent variables to examine different aspects of technological change. To measure the overall technological change in wind power, we use the per unit electricity

\footnotetext{
${ }^{3}$ All the CDM documents are available at: http://cdm.unfccc.int/Projects/projsearch.html.

${ }^{4}$ We use installed capacity data from 2002 to 2008 to calculate the previous installation experience that a developer or a manufacturer has. The non-CDM installed capacity only accounts for $13 \%$ of the total installed capacity in China.
} 
production cost of the wind farm as our primary dependent variable, enabling us to compare our results with the previous literature on technological learning in wind power. To further explore how different learning channels drive down the unit production cost, we decompose the overall learning effects into two subsystems of learning: wind farm construction and installation, and wind farm operation. We examine these two subsystems by looking at capital cost per kWh and the capacity factor of the wind farm correspondingly.

\section{1) Electricity production cost}

The primary dependent variable is the projected unit cost of electricity production of project $i$ that starts construction in year $t$ (Unit_cost $t_{i t}$ ), also known as the levelized cost. We calculate the per unit production cost by dividing the project life cost by its life electricity production estimated in the project financial analysis, which captures the projected average cost of generating one unit $(\mathrm{kWh})$ of electricity by the project. The unit cost is calculated as follows:

$$
\left(\text { Unit_cost }_{i t}=\sum_{j=1}^{n} \frac{\text { Capital }_{j}+O \& M_{j}}{(1+r)^{j}} / \sum_{j=1}^{n} \frac{\text { Electricity }_{j}}{(1+r)^{j}}\right.
$$

where $\boldsymbol{C a p t i t a l}_{\boldsymbol{j}}$ is the static construction investment in the $\boldsymbol{j}^{\text {th }}$ year in project life, $\boldsymbol{O} \boldsymbol{\&} \boldsymbol{M}_{\boldsymbol{j}}$ is the annual operation and maintenance expenditures in year $\boldsymbol{j}$, and Electricity $_{j}$ represents the annual electricity generated by the wind farm in year $\boldsymbol{j} .{ }^{5}$ Both project costs and electricity production are discounted at a discount rate $\boldsymbol{r}=8 \%$, which is the industrial benchmark IRR on total investment. ${ }^{6}$ The year that project $\boldsymbol{i}$ starts construction, represented by $\boldsymbol{t}$, corresponds to the first year in its project life (i.e. $j=1$ ). We adjust all cost variables to 2005 prices.

\footnotetext{
${ }^{5}$ Although the annual electricity production data we collect from validated CDM project design documents are estimated generation, the electricity generation is monitored after the project starts its operation. According to the monitoring reports that we have examined, the estimated annual electricity production is very close to the actual electricity generation.

${ }^{6}$ According to the State Power Corporation's “Interim Rules on Economic Assessment of Electrical Engineering Retrofit Projects”, the benchmark IRR for a project in power industry is $8 \%$ of the total investment.
} 
While the cost data from CDM project design documents and financial analyses are expected costs, using the CDM data provides several advantages. To prove additionality, proposed projects must not be financially viable without the revenue from selling emissions credits. Thus, project developers have no incentive to understate costs, which would overestimate technological progress. At the same time, since we only use projects that have been validated and registered, the proposed project costs have been evaluated by independent auditors. Projected costs that are unreasonably high would lead to rejection of a proposed project. For capital costs, the validating agencies usually crosscheck estimated capital costs with the actual costs specified in construction and equipment purchase contracts. According to the CDM validation guidelines and the validation reports we have examined, the estimated capital costs are very close to the real capital investment. Moreover, many project design documents used actual capital costs in their financial analyses. ${ }^{7}$ For O\&M costs, the auditing agencies compared the estimated costs with public statistics and other similar CDM wind projects. Based on the comparison, they must determine that the projected O\&M cost data used in CDM project design document are reasonable before validating the project. Thus, we believe that our cost measurement is more reasonable and credible than the national concession bidding prices used by Qiu and Anadon (2012). As discussed in section 2.1, bidding prices in the national concession program may be much lower than the actual price, which is often a strategy used by developers to win the project first without considering the long-term project profitability (Li et al., 2008; Yang et al, 2009; Wang, 2010). Absent the availability of

\footnotetext{
${ }^{7}$ To rule out the possibility that the project developers learn to produce more accurate cost estimation over time, we used stratified sampling to select 51 of our 510 projects by the year that a project started construction. For projects before 2006, the validation reports do not provide actual cost data, but they claim that they have cross-checked with the actual data and the estimation are consistent with the actual capital investment. For projects starting from 2006 to 2009, the estimated costs are very close to the real capital costs for all years. Based on this validation, we believe that the possibility of better cost estimation is small.
} 
actual cost data for Chinese wind farms, we believe that our validated CDM data provide the most accurate representation of electricity production costs for wind projects in China.

\section{2) Unit capital cost}

Wind farm capital investment costs have a major influence on the costs of electricity production (Junginger et al., 2005). Investment costs include costs such as turbine foundations, land, grid connection, civil works, and turbine installation. We calculate the estimated unit capital cost in a similar way to total unit costs:

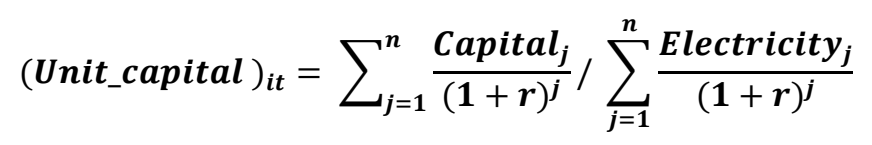

\section{3) Capacity factor}

We use projected capacity factor to measure the operational performance of a wind farm. The capacity factor is the ratio of the actual electricity produced by a wind farm in a given period to its potential output if the wind farm was operated at full nameplate capacity for the entire period. We calculate the capacity factor of a CDM wind project using the following formula:

$$
(C F)_{i t}=\frac{\text { Annual Electiricity }}{24 h r s / \text { day } * 365 \text { days } * \text { Proejct Size }}
$$

The capacity factor of a wind farm is mostly determined by the availability of wind on the site. Given the wind quality in a particular region, we expect additional experience will help a developer pick a better site, select suitable wind turbines and make the best use of the wind resource at the site, all of which lead to increased capacity factor. In addition, the quality of wind turbines and the interactions between the developer and its turbine manufacturing partners may also help to improve performance.

\subsection{Manufacturer's knowledge stock}


To test the effect of learning by searching on electricity production cost, we create a manufacturer's knowledge stock ( $\left.\boldsymbol{L} \boldsymbol{B} \boldsymbol{S}_{\boldsymbol{m} f t}\right)$, using cumulative patent applications related to wind power from the manufacturer supplying wind turbines to project $i$. We lag the manufacturer's knowledge stock to account for the time needed to convert an innovation to mass manufacturing. Since knowledge related to wind power may depreciate over time, we use a 15\% depreciation rate to calculate the knowledge stock in our empirical model, which is a typical knowledge decay rate used in the R\&D literature (Griliches, 1995; Popp, 2004). ${ }^{8}$ The knowledge stock variable is calculated as follow:

$$
L B S_{m f t}=L B S_{t-1} *(1-\rho)+N P_{t-1}
$$

where $\boldsymbol{L} \boldsymbol{B} \boldsymbol{S}_{t-1}$ represents the existing knowledge stock from year $t-1, \boldsymbol{\rho}$ is the depreciation rate, and $\boldsymbol{N} \boldsymbol{P}_{t-1}$ represents the number of new patents that the manufacturer applied for in year $t-1$.

We identify each turbine manufacturer's patent applications in China relevant to wind energy, which include innovations pertaining to wind turbine manufacturing, installation, testing and monitoring, and maintenance. ${ }^{9}$ We date these applications by the priority date, as this corresponds most closely to when the innovative activity actually took place. ${ }^{10}$ We use data collected for each manufacturer by year to calculate the cumulative knowledge stock. If a CDM project use wind turbines from two manufacturers, we calculate the weighted average knowledge stock using the shares of their installed capacity in this project as weights.

\footnotetext{
${ }^{8}$ We also test the effects of knowledge stock calculated with a $10 \%$ depreciation rate. The results are not sensitive to the choice of discount rates.

${ }^{9}$ We identify the relevant patents by using the International Patent Classification (IPC), which is a classification system developed by the World Intellectual Property Organization and used by patent offices around the world to identify the technology represented in each patent. IPC classification F03D represents wind energy patents.

${ }^{10}$ For a patent application, priority date is the earliest application date anywhere in the world.
} 


\subsection{Experience at different levels and spillovers}

We test the effects of wind project developing and operating experience for different participants and at different levels. At the micro level, we have a project developer's experience $\left(L B D_{d e v}\right)$ and the turbine manufacturer's experience $\left(L B D_{m f t}\right)$. At the aggregate level, we test the spillover effects of provincial level wind project experience (Spill $l_{\text {province}}$ ) and the experience from the whole industry (Spillindustry). The experience variables are measured by the cumulative installed capacities through year $t$-1 at developer level, manufacturer level, province level, and industrial level respectively. To test the spillover effects, the experience of project $i$ 's developer and manufacturer is subtracted from the aggregate level experience, so that aggregate experience for each project $i$ can be interpreted as the experience of the rest of the industry.

Finally, we measure collaboration between a project developer and manufacturer (LBI) by calculating the cumulative capacity of previous CDM projects using both the same developer and manufacturer. This can be thought of as the shared CDM experience between the developer and the manufacturer. If a CDM project use wind turbines from two manufacturers, we calculate the weighted average cooperating CDM experience using the shares of their installed capacity in this project as weights.

\subsection{Control variables}

To accurately assess the impact of learning on our dependent variables, we must also control for other project features that affect the unit production costs or productivity:

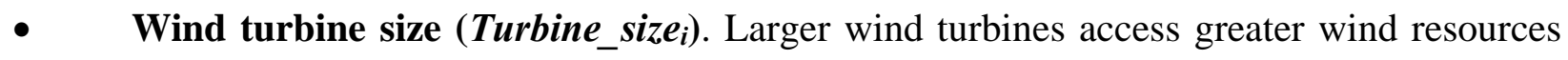
available at greater heights, allowing them to capture more energy so as to produce more power. If a CDM project has more than one type of wind turbine, we use average wind turbine size. 
- Wind project scale (Project_size $e_{i}$ ). Wind projects with larger installed capacity will have economies of scale. As a result, the unit production cost will be reduced (Berry 2009, Qiu and Anadon, 2012; Partridge, 2013).

- Wind resource quality. If the project site has better wind resources, it should have higher productivity. The wind resource quality is measured by dummy variables $\boldsymbol{W}_{1 i}, \boldsymbol{W}_{2 i}, \boldsymbol{W}_{3 i} \boldsymbol{W}_{4 i}$, representing the four wind resource categories specified by the 2009 Feed-in Tariffs for Wind Power in China (NDRC, 2009). $W_{l i}$ indicates that project $i$ is located in the best wind quality region while $W_{4 i}$ indicates the region with the least wind resources.

- $\quad$ Characteristics of manufacturers and developers. If the wind turbine manufacturer is a foreign company, Foreign $\boldsymbol{m}_{\boldsymbol{m f t}}$ equals to 1. Although some foreign manufacturers have developed subsidiaries in China, we still treat them as foreign manufacturers because their patents belong to the parent companies.

We also control for the ownership of the project developer. We classify project developers into three groups based on their ownership and market power in electricity generation market: state-owned enterprises (SOE) regulated and supervised by central government, SOEs regulated and supervised by local government, and private enterprises (Li et al., 2012). We expect that central SOE developers, on average, have the lowest production costs among the three categories because they dominate the electricity generation market and have more bargaining power when developing a wind project. By the end of 2011, the top nine central SOE developers contributed 73.8\% of China's cumulative installed capacity (Li et al., 2012). From 2006 to 2010, SOEs developed 90\% of wind projects in China (Li et al., 2010 \& 2012).

Table 2 summarizes the description of explanatory variables for different channels of learning and control variables. 
[Table 2]

\subsection{Descriptive statistics}

Table 3 reports summary statistics for the major variables used in our empirical models.

[Table 3]

Figure 3 shows the trend of the average unit cost of CDM projects started from 2004 to 2009. ${ }^{11}$ We also decompose the unit cost into the unit capital cost and unit O\&M cost. All costs are calculated using 2005 prices. In Figure 3, we see that the unit production cost and its two components generally have downward trends from 2005 to 2009, which is consistent with the rapid technological progress in China's wind power during this period. The unit project cost falls by $12.1 \%$ and the unit capital cost falls by $10.8 \%$. Unit O\&M cost drops most sharply, decreasing $17.4 \%$ from 2005 to $2009 .{ }^{12}$

[Figure 3]

While we observe that the average project unit cost and its components have downward trends from 2005 to 2009, project capacity factors, as shown in Figure 4, do not show a clear trend during this period. Since the capacity factor is mainly determined by the wind resource available, one possibility is that projects started earlier could pick sites with better wind resources, leaving limited choices for later projects.

\section{[Figure 4]}

\section{Empirical Model and Results}

To explain what has led to the project cost reduction over time, we test the effects of different learning channels gradually in three steps using OLS regressions, with each step adding

\footnotetext{
${ }^{11}$ Although the earliest CDM wind projects in China started in 2002, we cannot calculate their unit costs due to missing data in their project design documents.

${ }^{12}$ While the average project cost is lower in 2004, we only have one observation that has cost data among the 4 projects that started in 2004 in our sample. Thus, these data may not be representative of all the projects in 2004.
} 
additional detail on the level of learning from experience. First, we test the effects of aggregate experience, using only province level experience and experience from the nation as a whole. In the second step, we separate both the developer's and the manufacturer's project experience from aggregate experience. In the last step, we test the effects of learning-by-interacting by further separating the shared CDM project experience between the developer and the manufacturer from their cumulative individual experience. In all three steps, we examine the effect of learning-bysearching from the manufacturer.

In addition to testing the learning effects on overall electricity production costs, we further examine the two subsystems of learning - wind farm installation and operation - by using unit capital cost and capacity factor as dependent variables correspondingly. This allows us to see where the cost reduction occurs and how different learning channels influence the subsystems of electricity production.

\subsection{Aggregate level experience}

As the first step, we test the effects of provincial and industrial level experience using equation (2), which includes the manufacturer's knowledge stock, provincial installation experience, and nation-wide installation experience. We subtract provincial experience from national level experience to separate spillovers from the province where a project is located from spillovers due to experience in other provinces. ${ }^{13}$

$$
\begin{aligned}
\ln \left(\text { Unit_cost }_{i t}\right)= & \beta_{0}+\beta_{1} L B S_{m f t}+\beta_{2} \text { Spill }_{\text {province }}+\beta_{3}\left(\text { Spill }_{\text {industry }}-\text { Spill }_{\text {province }}\right)+\beta_{4} X_{i}+ \\
& \text { Province }+ \text { Year }+u_{i}
\end{aligned}
$$

\footnotetext{
${ }^{13}$ While most learning models use a log-log format, so as to interpret the coefficients as learning rates, we do not use logs for our explanatory variables as we have many zeros when decomposing experience in the later models.
} 
To control for the effects of other factors that influence electricity production cost, we also include all the control variables listed in Table 2, represented by $X_{i}$ in equation (2). We use province dummies to control for time-invariant heterogeneity across provinces, such as topographical and meteorological features, transmission infrastructure, and the investment environment. We further add year fixed effects to control for other omitted variables that change over time for all projects starting in the same year, such as national policies, input prices, global changes in technology, and other unobserved factors.

[Table 4]

Table 4 reports the estimates of learning-by-searching effects and the effects of aggregate level wind project developing and operating experience on unit production costs. We estimate three models adding different fixed effects. The learning-by-searching effect, captured by manufacturer's knowledge stock, is significant across all three models. However, the magnitude of the LBS effect is very small. In the short run, one more patent from the manufacturer reduces unit costs by just $0.04 \%$. For the learning-by-doing effect, the aggregate level project developing experience variables have significant negative effects on unit production costs only in models (1) and (2), which omit year fixed effects. When we add year fixed effects in model (3), the aggregate province level experience becomes insignificant. We do not include industrial level experience when adding year fixed effects to the model, as the sum of provincial experience and industrial experience equals the total industry-wide capacity in a given year, and is thus correlated with the year fixed effects.

While the evidence of learning from macro level project experience is not clear, the results for other control variables are as expected. Both project size and wind resource quality significantly influence the project unit cost and the effects are consistent with existing literature. 
Projects with larger size benefit from economies of scale, leading to a reduction of electricity production cost. Projects located in regions with lower wind resource quality have higher unit electricity generation cost than projects in regions with better wind quality.

Characteristics of the turbine manufacturer and project developer also significantly affect electricity production cost. On average, the unit costs of projects using wind turbines supplied by foreign manufacturers are $4 \%$ to $5 \%$ higher than projects using wind turbines from domestic manufacturers, suggesting that turbines from foreign manufacturers have higher prices than domestic wind turbines even after controlling for a manufacturer's knowledge stock embedded in the turbines. Indeed, previous research has found that the higher costs of purchasing foreign wind turbines is one reason that Chinese developers to apply for the CDM support (Wang, 2010). The unit production costs of projects developed by central SOE developers are estimated to be approximately $4 \%$ to $5 \%$ lower than the costs of private developers' projects.

\subsection{Effect of developer's internal experience and spillover effects}

In the second step, we consider each project developer and manufacturer's individual experience. To do so, we must also subtract the developer's experience, $\boldsymbol{L} \boldsymbol{B} \boldsymbol{D}_{d e v}$, and the manufacturer's experience, $\boldsymbol{L B D}_{\boldsymbol{m} f t}$, from the aggregate level experience, $\boldsymbol{S p i l l}_{\text {industry }}$. The empirical model specification becomes:

$$
\begin{aligned}
\ln \left(\text { Unit_cost }_{i t}\right)= & \beta_{0}+\beta_{1} L B S_{m f t}+\beta_{2} L B D_{m f t}+\beta_{3} L B D_{\text {dev }}+\beta_{4} \text { Industry_spill }+ \\
& \beta_{5} X_{i}+\text { Province }+ \text { Year }+u_{i}
\end{aligned}
$$

where Industry_spill is the knowledge spillover from other projects in the industry. ${ }^{14}$

Table 5 shows the regression results of equation (3). Once again we estimate three model

\footnotetext{
${ }^{14}$ In equation (3), Industry_spill $=\boldsymbol{S p i l l}_{\text {industry }}-\boldsymbol{L B D}_{\text {dev }}-\boldsymbol{L} \boldsymbol{B} \boldsymbol{D}_{\boldsymbol{m} f t}+\boldsymbol{L B I} \mathbf{L} \boldsymbol{L} \boldsymbol{B I}$ is the previous cooperating experience on joint projects between a developer and a manufacturer, which overlap between $\boldsymbol{L} \boldsymbol{B} \boldsymbol{D}_{\boldsymbol{m} f t}$ and $\boldsymbol{L} \boldsymbol{B} \boldsymbol{D}_{\boldsymbol{d e v}}$. Thus, we add it back to avoid double subtraction from industrial experience.
} 
specifications with different fixed effects. The LBS effect is significant across all the models and the magnitude is similar to what we have found in 5.1. As we separate the developer's CDM project experience and manufacturer's experience from the aggregate level experience, we observe that learning from the developer's previous CDM project experience significantly reduces the project unit cost across all three models. With year fixed effects in model (3), the magnitude of the coefficient on developer's experience shows that the unit cost of wind power in CDM projects nearly falls by $4 \%$ for each additional $1 \mathrm{GW}$ of previous installed capacity in CDM projects by the developer. Given that the average size of a CDM wind project is approximately $60 \mathrm{MW}$, a typical CDM project by the same developer leads to a $0.23 \%$ to $0.25 \%$ decrease in future unit costs. Most central SOE developers and some local SOE developers have around 10 new CDM projects in 2009, so that it will only take one to two years for these developers to increase capacity by $1 \mathrm{GW}$. In contrast to developer experience, the manufacturer's previous project experience does not have a significant effect on unit production costs.

\section{[Table 5]}

While we find some evidence of industry-level spillovers in section 5.1, the importance of these spillovers disappears when we separate learning effects into experience of the turbine manufacturer and experience of the project developer. In contrast, previous studies that find evidence of wind power firms learning from the industrial experience (Nemet, 2012; Qiu and Anadon, 2012) do not separately control for the experience of different actors in the industry.

\subsection{Effects of collaborating experience and other channels of learning}

Finally, we examine the role of collaboration in CDM wind projects. Here, we consider experience on joint projects between a developer and a manufacturer separately from both the developer and manufacturer's experience on other projects. The empirical model is: 


$$
\begin{gathered}
\ln \left(\text { Unit_cost }_{i t}\right)=\beta_{0}+\beta_{1} L B S_{m f t}+\beta_{2} L B D_{m f t a l o n e}+\beta_{3} L B D_{\text {dev_alone }}+\beta_{4} L B I+ \\
\beta_{5} \text { Industry_spill }+\beta_{6} X_{i}+\text { Province }+ \text { Year }+u_{i}
\end{gathered}
$$

where $\boldsymbol{L B I}$ represents the shared cumulative installed capacities in CDM projects between the developer and the manufacturer. We separate this shared experience from their own cumulative installed capacities. ${ }^{15}$ In this way, we are able to examine the effect of learning-by-doing and learning-by-interacting separately. Industry_spill is the knowledge spillover from other projects in the industry as calculate in section 5.2.

Table 6 reports the estimates of different learning effects. Model (1) only has province fixed effects and Model (2) adds year fixed effects. Model (3) further includes an interaction term between foreign manufacturer dummy and the previous cooperating experience between the developer and manufacturer in order to tests whether the collaboration with a foreign manufacturer makes a difference on production costs.

\section{[Table 6]}

Across all three specifications, we see that the LBS effects are significant and the magnitudes are similar to the results in Table 5. For LBD effects, a developer's experience alone matters, but the impact is smaller than found in the previous section, where a developer's experience includes shared experience with the manufacturer.

What reduces project costs the most is repeated collaboration experience between a developer and the same manufacturer, which suggests the learning-by-interacting effect. A $1 \mathrm{GW}$ increase of collaborative installed capacity results in approximately a $4 \%$ decrease of the unit electricity production cost. This magnitude indicates that each additional CDM wind project that the developer and the manufacturer build together decreases unit costs by about $0.25 \%$. In column

\footnotetext{
${ }^{15}$ In equation (4), $\boldsymbol{L} \boldsymbol{B} \boldsymbol{D}_{m f t a l o n e}=\boldsymbol{L B} \boldsymbol{D}_{m f t}-\boldsymbol{L B I}$, and $\boldsymbol{L} \boldsymbol{B} \boldsymbol{D}_{\text {dev_alone }}=\boldsymbol{L} \boldsymbol{B} \boldsymbol{D}_{\text {dev }}-\boldsymbol{L B I}$.
} 
(3), the significance of the interaction term with foreign manufacturers suggests that collaborations between developers and foreign manufacturers generate the greatest cost savings. An additional 1 GW installed capacity by a developer with its foreign manufacturer partner drives down the unit production cost by approximately $15.7 \%,{ }^{16}$ which is nearly three times greater than the effect of cooperating experience between a developer and a domestic manufacturer. Thus, each additional $\mathrm{CDM}$ wind project that a developer builds with the same foreign manufacturer will reduce the unit cost by almost $1 \%$. The difference between cooperating experience with foreign manufacturers and domestic manufacturers on unit cost reduction suggests that tacit knowledge transfer between foreign manufacturers and project developers is important to maximize the benefits from the transfer of foreign technologies.

\subsection{Learning effects on unit capital cost and capacity factor}

Finally, we use capital cost per kWh and the project capacity factor as dependent variables to test the effects of different learning channels on wind farm installation and operation. As shown in Table A1 and A2 in the appendix, the impacts of manufacturer's knowledge stock, manufacturer and the developer's experience alone, and the spillover from the industrial level on unit capital cost and capacity factor are highly consistent with what we have found for unit production costs.

However, collaborating experience between the manufacturer and project developer has different impacts on unit production cost, unit capital cost, and capacity factors. Table 7 compares models with different dependent variables. All models include both province fixed effects and year fixed effects. For comparison, columns (1) and (2) repeat the results shown in columns (2) and (3) of Table 6.

[Table 7]

16 The percentage change is exp $(-0.0397-0.131)-1=-15.7 \%$. 
As shown in model (1) and model (3), learning by interacting effects, captured by repeated collaboration experience, lead to both production cost reduction and capital cost reduction. The magnitude of the effect for capital cost reduction is slightly larger than the effect on production reduction. However, cooperating experience does not have a significant effect on capacity factor in model (5). When we further test whether cooperating with a foreign manufacturer makes a difference by adding the interaction terms in model (2), (4) and (6), cooperation with a foreign manufacturer leads to a greater reduction for electricity production costs while it makes no difference on capital costs and capacity factor.

The results above indicate that repeated partnerships between a developer and manufacturer mostly drive down the costs of construction and installation stage, but do not lead to better operational performance, as measured by capacity factor. Instead, the developer's own experience is sufficient to provide guidance on siting turbines to improve the electricity generated from each new site. Since the unit capital costs on average account for approximately $80 \%$ of the unit electricity production cost of a wind project, we also observe that the cooperating experience matters most for the production cost reduction on the whole. When we further differentiate between cooperating experience with foreign manufacturers and domestic manufacturers, our results suggest that a repeated partnership with a foreign manufacturer facilitates knowledge diffusion between partners beyond the construction and installation stage, as the foreign manufacturer interaction is statistically significant in the model using overall costs as the dependent variable.

\section{Conclusions}

Using CDM wind projects started between 2002 and 2009 in China, this paper examines the effects of different channels of learning - learning through R\&D in wind turbine 
manufacturing, learning from firm's previous experience of installation, learning from the experience of other firms, and learning through collaboration between wind turbine manufacturer and project developer—on technological change in China's wind. We consider the impacts of these learning channels on the unit cost of electricity generation, as well as on wind farm installation costs and capacity factor.

Our empirical analysis successfully separates the learning-by-searching effect from the joint learning effect of LBS and LBD used in previous research on China's wind industry. However, the learning-by-searching effect is much smaller than what has been found for European wind power over a longer period of time (Soderholm \& Klassen, 2007; Soderholm \& Sundqvist, 2007). This is reasonable because our observation period is too short for patents to be fully commercialized and to have large impact on cost reduction. Another reason could be that turbines with advanced technology have higher prices while the electricity production is limited by the technological capacity of the developer or the transmission system.

Our results also provide evidence of learning-by-doing for wind project developers in China. While finding LBD effects is consistent with previous research, our paper is the first to separately identify the experience of manufacturers and project developers. Developers are more likely to benefit from their past internal experience in both wind farm installation and operation, which significantly drive down the overall electricity production costs. Unlike previous research, when we separate the experience of developers and manufacturers from the industrial experience, the experience of other manufacturers and developers are less important to the observed project. However, it does not contradict the findings in the work of Qiu and Anadon (2012) because their measurement for industrial learning also includes the experience and knowledge stock of the turbine manufacturer involved in an observed project while we partial out these effects. On the 
whole, the learning-by-doing effect itself provides support for demand-side subsidies, such as CDM revenues, to price negative externalities and stimulate demand so as to provide opportunities for learning-by-doing and reduce future abatement costs.

Most importantly, we find that what really matters for reducing electricity production costs is not just the experience of a particular project developer or turbine manufacturer, but the joint project experience between the developer and the same manufacturer through their repeated interaction. The repeated partnership between developers and turbine manufacturers leads to lower electricity production costs, particularly for capital costs. Our results provide justification for the trend of integrating turbine manufacturing with wind project developing in China's wind industry. Both domestic manufacturers such as Goldwind and foreign manufacturers such as Gamesa have begun to either form subsidiaries to develop wind projects or partner with certain existing developers in order to get more involved in project development ( $\mathrm{Li}, 2012)$. This finding also suggests that the wind energy association or local government could set up platforms or forums to connect developers and manufacturers in advance, particularly for small developers that newly enter the market.

One goal of CDM is to enable technology transfer and the subsequent diffusion of climatefriendly technologies in countries hosting CDM projects. Our results also provide evidence that, by encouraging cooperation between local project developers and turbine manufacturers, the CDM is successful in this goal. However, more research is necessary to establish the mechanisms through which these partnerships cause costs to fall. While it may be the case that the reduction of capital costs is a result of joint learning between the developers and manufacturers on wind farm installation, we cannot rule out that the cost savings are simply the result of economically reciprocal wind turbine purchase contracts between partners based on their repeated collaboration. 
Distinguishing between these explanations requires further qualitative data to rule out the latter explanation or to separate the impacts of these two explanations.

Finally, our strongest evidence for the learning-by-interacting effect occurs when a wind project developer repeatedly collaborates with a foreign manufacturer. In addition to the transfer of physical technology, the transfer of tacit knowledge through the partnership drives down the electricity production cost to a great extent. In the light of this finding, it may not be wise for Chinese government to prevent foreign manufacturers from entering and competing with other domestic manufacturers in the turbine manufacturing market. 


\section{References}

Arrow, K., 1962. The economic implications of learning by doing. The Review of Economic Studies, 29(3): 155-173.

Berry, D., 2009. Innovation and the price of wind energy in the US. Energy Policy, 37: 44934499.

Cohen, W. M., Levinthal, D.A., 1990. Absorptive Capacity: A New Perspective on Learning and Innovation. Administrative Science Quarterly, 35(1): 128-152.

Dechezlepretre, A., Glachant, M. and Y. Meniere. 2008. The clean development mechanism and the international diffusion of technologies: an empirical study. Energy Policy, 36:1273-1283.

Dechezlepretre, A., Glachant, M and Y. Meniere. 2009. Technology transfer by CDM projects: A comparison of Brazil, China, India and Mexico. Energy Policy, 37: 703-711.

GWEC, 2012. Global Wind Report 2011. Global Wind Energy Council Report. Available at: http://gwec.net/wp-content/uploads/2012/06/Annual_report_2011_lowres.pdf.

Griliches, Z., 1995. R\&D and Productivity: Econometric Results and Measurement Issues. Handbook of the Economics of Innovation and Technological Change, Paul Stoneman, ed., Blackwell Publishers, Cambridge, MA.

Grubler, A., 1998. Technology and global change. Cambridge University Press, Cambridge, United Kingdom.

Grubler, A., Nakicenovic, N., Victor, D.G., 1999. Dynamics of energy technologies and global change. Energy Policy, 27: 247-280.

Hascic, I. and Johnstone, N., 2011. Clean Development Mechanism and International Technology Transfer: Empirical Evidence on Wind. Climate Policy, 11(6): 1303-1314.

Huang, C., Su, J., Zhao, X., Sui, J., Ru, P., Zhang, H., Wang, X., 2012. Government funded renewable energy innovation in China. Energy Policy, 51: 121-127.

Ibenholt, K., 2002. Explaining learning curves for wind power. Energy Policy, 30(13): 1181-1189.

Inkpen, A., Beamish, P. W., 1997. Knowledge Bargaining Power, and the Instability of International Joint Ventures. Academy of Management Review, 22(1): 177-202. 
Inkpen, A., Currall, S.C., 2004. The Coevolution of Trust, Control and Learning in Joint Ventures. Organization Science, 15(5): 586-599.

Jaffe, A.B., Newell, R.G., Stavins, R.N., 2005. A tale of two market failures: Technology and environmental policy. Ecological Economics, 54: 164-174.

Junginger, M., Faaij, A., Turkenburg, W.C., 2005. Global experience curves for wind farms. Energy Policy, 33, 133-150.

Junginger, M., Lako, P., Lensink, S., Sark, W.V., Martin Weisss, M., 2008. Technological learning in the energy sector. Report WAB 500102017. Netherlands Environmental Assessment Agency, Bilthoven.

Kahouli-Brahmi, S., 2008. Technological learning in energy-environment economy modeling: a survey. Energy Policy, 36: 138-162.

Koppenjan, J., Klijn, E., 2004. Managing Uncertainty in Networks: A Network Approach to Problem Solving and Decision Making. New York, NY: Routledge.

Lewis, J., 2010. The evolving role of carbon finance in promoting renewable energy development in China. Energy Policy, 38: 2875-2886.

Lewis,J., 2013.Green Innovation in China: China's Wind Power Industry and the Global Transition to a Low-Carbon Economy. Columbia University Press, New York.

Li, J.F., Gao, H., Ma, L.J., Wang, Z.Y., Dong, L.Y., 2008. China wind power outlook 2008. China Environmental Science Press, Beijing.

Li, J.F., Shi, P.F., Gao, H., 2010. China wind power outlook 2010. China Environmental Science Press, Beijing.

Li, J.F., 2012. China wind power outlook 2012. China Environmental Science Press, Beijing.

Lin, W., Heggelund, G., Tangen1, K., and Li, JF., 2004. Efficient implementation of CDM in China. FNI-R0104, Fridtjof Nansen Institute. Available at: http://www.fni.no/doc\&pdf/FNIR0104.pdf.

NDRC, 2009. Notice on improving wind power on-grid electricity pricing policy. National Development and Reform Commission of People's Republic of China. 
Nemet, G. F., 2006. Beyond the learning curve: Factors influencing cost reductions in photovoltaics. Energy Policy, 34: 3218-3232.

Nemet, G.F., 2012. Knowledge spillovers from learning by doing in wind power. Journal of Policy Analysis and Management, 31(3): 600-621.

Patridge, I., 2013. Renewable electricity generation in India - A learning rate analysis. Energy Policy, 60: 906-915.

Popp, D., 2004. ENTICE: endogenous technological change in the DICE model of global warming. Journal of Environmental Economics and Management, 48: 742-768.

Popp, D., 2011. International Technology Transfer for Climate Policy. Review of Environmental Economics and Policy, 5(1): 131-152.

Qiu, Y., Anadon, L.D., 2012. The price of wind power in China during its expansion: Technology adoption, learning-by-doing, economies of scale, and manufacturing localization. Energy Economics, 34: 825-835.

Ru, P., Zhi,Q., Zhang,F., Zhong,X.T., Li,J.Q., Su,J.,2012. Behind the development of technology: the transition of innovation modes in China's wind turbine manufacturing industry. Energy Policy, 43 (April): 58-69.

Schneider, M., 2008. Understanding the CDM's contribution to technology transfer. Energy Policy, 36: 2930- 2938.

Schneider, M., Schmidt, T., and Hoffmann, V., 2010. Performance of renewable energy technologies under the CDM. Climate Policy, 10(1): 17-37.

Schmid, G., 2011. Technology Transfer in the Clean Development Mechanism: the role of the Host Country Characteristics. University of Geneva, working paper series 11102.

Seres, S., 2007. Analysis of Technology Transfer in CDM Projects. UNFCC Secretariat, Bonn.

Seres, S., 2009. Analysis of Technology Transfer in CDM Projects: An Update. Energy Policy 37: 4919-4926.

Söderholm, P., Klaassen, G., 2007. Wind power in Europe: a simultaneous Innovation-diffusion model. Environmental and Resource Economics, 36 (2): 163-190. 
Söderholm, P., Sundqvist, T., 2007. The empirical challenges of measuring technology learning in the renewable energy sector. Renewable Energy, 32 (15): 2559-2578.

Taylor, M., Thornton, D., Nemet, G., Colvin, M., 2006. Government actions and innovation in environmental technology for power production: the cases of selective catalytic reduction and wind power in California. California Energy Commission, PIER Energy-Related Environmental Research, CEC-500-2006-053.

Thorton, R.A., Thompson, P., 2001. Learning from Experience and Learning from Others: An Exploration of Learning and Spillovers in Wartime Shipbuilding. American Economic Review, 91(5): 1350-1368.

Wang, B., 2010. Can CDM bring technology transfer to China?-An empirical study of technology transfer in China’s CDM projects. Energy Policy, 38: 2572-2585.

Wang, Q., 2010. Effective policies for renewable energy - the example of China's wind power lessons for China's photovoltaic power. Renewable and Sustainable Energy Reviews, 14: 702712 .

Wang, Z., Qin, H., Lewis, J., 2012. China’s wind power industry: Policy support, technological achievements, and emerging challenges. Energy Policy, 51: 80-88.

Yang, M., Nguyen, F., De T’Serclaes, P., and Buchner, B., 2010. Wind farm investment risk under uncertain benefit in China. Energy Policy, 38: 1436-1447.

Zhang, X., Chang, S., Huo, M., Wang, R., 2009. China's wind industry: policy lessons for domestic government interventions and international support. Climate Policy, 9(5): 553-564. 
Table 1: Matrix for China's Wind Technology Policy Tools

\begin{tabular}{|c|c|c|}
\hline & Domestic & International \\
\hline Supply Side & $\begin{array}{l}\text { - National basic research program (973 Program, } \\
\text { 1997) } \\
\text { - National high-tech R\&D program (863 Program, } \\
\text { 1986) } \\
\text { - National key technology R\&D program (TKPs, } \\
\text { 1982) }\end{array}$ & \\
\hline Demand Side & $\begin{array}{ll}\text { - } & \text { National wind concession program (2003-2008) } \\
\text { - } & \text { Power surcharge for wind power (2006) } \\
\text { The wind power share target in the Medium and } \\
\text { Long-Term Development Plan for Renewable } \\
\text { Energy in China (2007) } \\
\text { - Relief of VAT and import tax for wind turbines } \\
\text { (2008) } \\
\text { NDRC Notice on policy to improve grid-connected } \\
\text { power pricing for wind power generation (2009) }\end{array}$ & $\begin{array}{l}\text { The Clean Development } \\
\text { Mechanism (CDM) }\end{array}$ \\
\hline
\end{tabular}


Table 2: Key Variables in the Empirical Model

\begin{tabular}{|c|c|}
\hline Variables & Description \\
\hline$L B S_{m f t}$ & $\begin{array}{l}\text { Manufacturer's knowledge stock: Cumulative patents related to wind power that } \\
\text { the manufacturer has in year } t-1 \text {. }\end{array}$ \\
\hline$L B D_{m f t}$ & $\begin{array}{l}\text { Experience from manufacturer: Manufacturer's cumulative installed capacities } \\
\text { in year } t-1 .(\mathrm{GW})\end{array}$ \\
\hline$L B D_{d e v}$ & $\begin{array}{l}\text { Experience from project developer in CDM projects: Project developer's } \\
\text { cumulative installed capacities in CDM projects in year } t-1 \text {. (GW) }\end{array}$ \\
\hline Spill $_{\text {prov }}$ & $\begin{array}{l}\text { Experience from wind projects in a province: Cumulative installed capacities in } \\
\text { province } r \text { in year } t-1 \text {. (GW) }\end{array}$ \\
\hline Spill $_{\text {industry }}$ & $\begin{array}{l}\text { Experience from the whole industry: Cumulative installed capacities of the } \\
\text { whole industry in year } t-1 \text {. (GW) }\end{array}$ \\
\hline$L B I$ & $\begin{array}{l}\text { Collaborative experience between project developer and manufacturer: } \\
\text { Cumulative capacities installed by this developer and the same manufacturer in } \\
\text { previous CDM projects in year } t-1 \text {. (GW) }\end{array}$ \\
\hline \multicolumn{2}{|l|}{ Control Variables } \\
\hline Turbine_size $_{i}$ & The average size of wind turbines of project (=project size/numbers of turbines). \\
\hline Project_size $_{i}$ & The installed capacity of project $i$. \\
\hline$W_{1 i}, W_{2 i}, W_{3 i} W_{4 i}$ & Wind resources in the site of project $i$. \\
\hline Foreign $_{m f t}$ & Binary variable indicating whether the manufacturer in project $i$ is a foreign firm. \\
\hline$S O E_{d e v}$ & $\begin{array}{l}\text { Binary variable indicating whether the project developer in project } i \text { is a state- } \\
\text { owned enterprise regulated and supervised by the central government. }\end{array}$ \\
\hline$L S O E_{d e v}$ & $\begin{array}{l}\text { Binary variable indicating whether the project developer in project } i \text { is a state- } \\
\text { owned enterprise regulated and supervised by the local government. }\end{array}$ \\
\hline Private $_{\text {dev }}$ & $\begin{array}{l}\text { Binary variable indicating whether the project developer in project } i \text { is a private } \\
\text { firm. }\end{array}$ \\
\hline Province & Province dummies, control for regional time-invariant heterogeneity. \\
\hline Year & $\begin{array}{l}\text { Start year dummies, control for policies, input prices, and other omitted variables } \\
\text { changing over time. }\end{array}$ \\
\hline
\end{tabular}


Table 3: Summary Statistics

Sample Size: $\mathbf{N}=\mathbf{4 8 6}$

\begin{tabular}{|c|c|c|c|c|c|}
\hline Variables & Mean & Std.dev. & Median & Max & Min \\
\hline Unit cost $(2005 \mathrm{RMB} / \mathrm{kWh})$ & 0.523 & 0.076 & 0.513 & 1.007 & 0.335 \\
\hline Unit capital cost (2005 RMB/kWh) & 0.425 & 0.066 & 0.418 & 0.780 & 0.256 \\
\hline Unit O\&M cost (2005 RMB/kWh) & 0.098 & 0.028 & 0.094 & 0.227 & 0.011 \\
\hline Capacity factor & 0.252 & 0.028 & 0.252 & 0.339 & 0.144 \\
\hline $\begin{array}{l}\text { Manufacturer's knowledge stock } \\
\text { (Decay rate }=0.15 \text { ) }\end{array}$ & 18.40 & 37.30 & 6.53 & 228.75 & 0 \\
\hline $\begin{array}{l}\text { Manufacturer's cumulative } \\
\text { installed capacity }(\mathrm{GW})\end{array}$ & 0.703 & 0.779 & 0.388 & 2.621 & 0 \\
\hline $\begin{array}{l}\text { Developer's cumulative installed } \\
\text { capacity in CDM projects (GW) }\end{array}$ & 0.747 & 0.970 & 0.380 & 3.338 & 0 \\
\hline $\begin{array}{l}\text { Cooperating installed capacity in } \\
\text { CDM projects }(\mathrm{GW})\end{array}$ & 0.129 & 0.218 & 0.030 & 0.938 & 0 \\
\hline $\begin{array}{l}\text { Province level cumulative } \\
\text { installed capacity }(\mathrm{GW})\end{array}$ & 0.806 & 1.028 & 0.452 & 3.679 & 0 \\
\hline $\begin{array}{l}\text { Industrial level cumulative } \\
\text { installed capacity (GW) }\end{array}$ & 6.652 & 2.391 & 5.554 & 12.156 & 0.222 \\
\hline Average turbine size (MW) & 1.350 & 0.375 & 1.5 & 3 & 0.6 \\
\hline CDM project size (GW) & 0.059 & 0.049 & 0.050 & 0.401 & 0.009 \\
\hline Foreign manufacturer & 0.160 & 0.367 & 0 & 1 & 0 \\
\hline Central SOE developer & 0.704 & 0.457 & 1 & 1 & 0 \\
\hline Local SOE developer & 0.113 & 0.317 & 0 & 1 & 0 \\
\hline Private developer & 0.183 & 0.387 & 0 & 1 & 0 \\
\hline Wind category 1 & 0.198 & 0.399 & 0 & 1 & 0 \\
\hline Wind category 2 & 0.292 & 0.455 & 0 & 1 & 0 \\
\hline Wind category 3 & 0.123 & 0.329 & 0 & 1 & 0 \\
\hline Wind category 4 & 0.387 & 0.488 & 0 & 1 & 0 \\
\hline
\end{tabular}


Table 4: Effects of Aggregate Level Experience on Unit Production Cost

\begin{tabular}{lccc}
\hline & $(1)$ & $(2)$ & $(3)$ \\
Dependent Variables & $\ln ($ unit_cost) & $\ln ($ unit_cost) & $\ln ($ unit_cost) \\
\hline & & & \\
Knowledge stock & $-0.00036^{* * *}$ & $-0.00043^{* * *}$ & $-0.00037^{* *}$ \\
of manufacturer & $(0.00016)$ & $(0.00016)$ & $(0.00015)$ \\
Province level experience & $-0.01289^{* * *}$ & -0.00060 & 0.00457 \\
(GW) & $(0.00459)$ & $(0.00553)$ & $(0.00723)$ \\
Industrial level experience & -0.00198 & $-0.00767^{* * *}$ & \\
(GW) & $(0.00289)$ & $(0.00296)$ & \\
Turbine size (MW) & 0.00493 & 0.00296 & 0.01149 \\
& $(0.01768)$ & $(0.01499)$ & $(0.01503)$ \\
Project size (GW) & $-0.56645^{* * *}$ & $-0.36233^{* * *}$ & $-0.32164 * * *$ \\
& $(0.16180)$ & $(0.12352)$ & $(0.12414)$ \\
Wind category 1 & $-0.17891^{* * *}$ & $-0.12902^{* * *}$ & $-0.13557 * * *$ \\
& $(0.01620)$ & $(0.02883)$ & $(0.02839)$ \\
Wind category 2 & $0.11512^{* * *}$ & $-0.09189^{* * *}$ & $-0.09914 * * *$ \\
& $(0.01391)$ & $(0.02714)$ & $(0.02696)$ \\
Wind category 3 & $0.07442^{* * *}$ & -0.00964 & -0.00948 \\
& $(0.01733)$ & $(0.02484)$ & $(0.02184)$ \\
Foreign manufacturer & $0.04398^{* *}$ & $0.05392^{* * *}$ & $0.03793^{* *}$ \\
& $(0.01846)$ & $(0.01705)$ & $(0.01609)$ \\
Central SOE developer & $-0.05103^{* * *}$ & $-0.04428 * * *$ & $-0.04186^{* * *}$ \\
& $(0.01150)$ & $(0.01022)$ & $(0.01008)$ \\
Local SOE developer & 0.02538 & 0.02357 & 0.02352 \\
& $(0.02418)$ & $(0.02010)$ & $(0.01862)$ \\
Province fixed effects & No & Yes & Yes \\
Year fixed effects & No & No & Yes \\
Constant & $-0.52935^{* * *}$ & $-0.14135^{*}$ & -0.12832 \\
& $(0.02422)$ & $(0.08181)$ & $(0.09902)$ \\
Observations & 486 & & \\
R-squared & 0.396 & 486 & 486 \\
\hline & & 0.604 & 0.668 \\
\hline
\end{tabular}

Note: Robust standard errors in parentheses, ${ }^{* * *} \mathrm{p}<0.01,{ }^{* *} \mathrm{p}<0.05,{ }^{*} \mathrm{p}<0$.1. Industrial level experience omitted in model (3) with year fixed effects because the sum of provincial experience and industrial experience equals to the total industry-wide capacity in a given year, which is correlated with the year dummies. 
Table 5 Learning-by-doing Effect and Spillover Effect

\begin{tabular}{|c|c|c|c|}
\hline Dependent Variables & $\begin{array}{c}\text { (1) } \\
\ln (\text { unit_cost) }\end{array}$ & $\begin{array}{c}(2) \\
\ln (\text { unit_cost) } \\
\end{array}$ & $\begin{array}{c}\text { (3) } \\
\ln (\text { unit_cost) } \\
\end{array}$ \\
\hline knowledge stock of & $-0.00024^{*}$ & $-0.00035 * *$ & $-0.00029 * *$ \\
\hline $\begin{array}{l}\text { Manufacturer' experience } \\
\text { (GW) }\end{array}$ & $\begin{array}{l}-0.00223 \\
(0.00601)\end{array}$ & $\begin{array}{l}-0.00488 \\
(0.00489)\end{array}$ & $\begin{array}{l}-0.01816 \\
(0.02285)\end{array}$ \\
\hline $\begin{array}{l}\text { Developer's experience in } \\
\text { CDM projects (GW) }\end{array}$ & $\begin{array}{c}-0.03101 * * * \\
(0.00501)\end{array}$ & $\begin{array}{c}-0.02718 * * * \\
(0.00456)\end{array}$ & $\begin{array}{l}-0.03938 * \\
(0.02017)\end{array}$ \\
\hline $\begin{array}{l}\text { Spillover from the } \\
\text { industry (GW) }\end{array}$ & $\begin{array}{c}0.00161 \\
(0.00298)\end{array}$ & $\begin{array}{l}-0.00001 \\
(0.00248)\end{array}$ & $\begin{array}{l}-0.01605 \\
(0.02444)\end{array}$ \\
\hline Turbine size (MW) & $\begin{array}{l}0.00341 \\
(0.01754)\end{array}$ & $\begin{array}{c}0.00202 \\
(0.01464)\end{array}$ & $\begin{array}{c}0.01068 \\
(0.01481)\end{array}$ \\
\hline Project size (GW) & $\begin{array}{c}-0.57580 * * * \\
(0.15441)\end{array}$ & $\begin{array}{c}-0.38520 * * * \\
(0.12270)\end{array}$ & $\begin{array}{c}-0.34063 * * * \\
(0.12296)\end{array}$ \\
\hline Wind category 1 & $\begin{array}{c}-0.19221 * * * \\
(0.01299)\end{array}$ & $\begin{array}{c}-0.13382 * * * \\
(0.02839)\end{array}$ & $\begin{array}{c}-0.14092 * * * \\
(0.02805)\end{array}$ \\
\hline Wind category 2 & $\begin{array}{c}-0.11907 * * * \\
(0.01219)\end{array}$ & $\begin{array}{c}-0.08570 * * * \\
(0.02710)\end{array}$ & $\begin{array}{c}-0.09387 * * * \\
(0.02688)\end{array}$ \\
\hline Wind category 3 & $\begin{array}{c}-0.07856 * * * \\
(0.01674)\end{array}$ & $\begin{array}{l}-0.01146 \\
(0.02254)\end{array}$ & $\begin{array}{l}-0.01251 \\
(0.01974)\end{array}$ \\
\hline Foreign manufacturer & $\begin{array}{l}0.03483^{*} \\
(0.01821)\end{array}$ & $\begin{array}{c}0.04602 * * * \\
(0.01692)\end{array}$ & $\begin{array}{l}0.03097 * \\
(0.01607)\end{array}$ \\
\hline Central SOE developer & $\begin{array}{l}-0.02104^{*} \\
(0.01271)\end{array}$ & $\begin{array}{l}-0.01728 \\
(0.01135)\end{array}$ & $\begin{array}{c}-0.01624 \\
(0.01126)\end{array}$ \\
\hline Local SOE developer & $\begin{array}{c}0.03484 \\
(0.02453)\end{array}$ & $\begin{array}{l}0.03335^{*} \\
(0.02009)\end{array}$ & $\begin{array}{l}0.03259 * \\
(0.01885)\end{array}$ \\
\hline Province fixed effects & No & Yes & Yes \\
\hline Year fixed effects & No & No & Yes \\
\hline Constant & $\begin{array}{c}-0.52014 * * * \\
(0.02343)\end{array}$ & $\begin{array}{c}-0.38794 * * * \\
(0.09862)\end{array}$ & $\begin{array}{c}-0.45777 * * * \\
(0.10299)\end{array}$ \\
\hline $\begin{array}{l}\text { Observations } \\
\text { R-squared }\end{array}$ & $\begin{array}{c}486 \\
0.453\end{array}$ & $\begin{array}{c}486 \\
0.674\end{array}$ & $\begin{array}{c}486 \\
0.684\end{array}$ \\
\hline
\end{tabular}

Note: Robust standard errors in parentheses, ${ }^{* * *} \mathrm{p}<0.01,{ }^{* *} \mathrm{p}<0.05,{ }^{*} \mathrm{p}<0.1$. 
Table 6: Effects of Collaborating Experience and Other Channels of Learning

\begin{tabular}{|c|c|c|c|}
\hline Dependent Variables & $\begin{array}{c}(1) \\
\ln (\text { unit_cost) }\end{array}$ & $\begin{array}{c}(2) \\
\ln (\text { unit_cost) }\end{array}$ & $\begin{array}{c}\text { (3) } \\
\ln (\text { unit_cost) }\end{array}$ \\
\hline Knowledge stock of & $-0.00035 * *$ & $-0.00029 * *$ & $-0.00025^{*}$ \\
\hline manufacturer & $(0.00014)$ & $(0.00013)$ & $(0.00013)$ \\
\hline Manufacturer's experience & -0.00309 & -0.00211 & -0.00216 \\
\hline alone (GW) & $(0.00515)$ & $(0.00572)$ & $(0.00571)$ \\
\hline Developer's experience in & $-0.02418 * * *$ & $-0.02333 * * *$ & $-0.02230 * * *$ \\
\hline CDM projects alone (GW) & $(0.00611)$ & $(0.00658)$ & $(0.00655)$ \\
\hline Cooperating experience in & $-0.04976 * *$ & $-0.04149 * *$ & $-0.03971^{* *}$ \\
\hline CDM $(\mathrm{GW})$ & $(0.02037)$ & $(0.01874)$ & $(0.01876)$ \\
\hline Spillover from the & -0.00027 & & \\
\hline industry (GW) & $(0.00252)$ & & \\
\hline \multirow[t]{2}{*}{ Turbine size (MW) } & 0.00160 & 0.01068 & 0.00929 \\
\hline & $(0.01464)$ & $(0.01481)$ & $(0.01493)$ \\
\hline \multirow[t]{2}{*}{ Project size (GW) } & $-0.38001 * * *$ & $-0.34063 * * *$ & $-0.33709 * * *$ \\
\hline & $(0.12138)$ & $(0.12296)$ & $(0.12246)$ \\
\hline \multirow[t]{2}{*}{ Wind category 1} & $-0.13526 * * *$ & $-0.14092 * * *$ & $-0.14541 * * *$ \\
\hline & $(0.02881)$ & $(0.02805)$ & $(0.02850)$ \\
\hline \multirow[t]{2}{*}{ Wind category 2} & $-0.08587 * * *$ & $-0.09387 * * *$ & $-0.09348 * * *$ \\
\hline & $(0.02759)$ & $(0.02688)$ & $(0.02706)$ \\
\hline \multirow[t]{2}{*}{ Wind category 3} & -0.01283 & -0.01251 & -0.01419 \\
\hline & $(0.02243)$ & $(0.01974)$ & (0.01983) \\
\hline \multirow[t]{2}{*}{ Foreign manufacturer } & $0.04596 * * *$ & $0.03097 *$ & $0.03969 * *$ \\
\hline & $(0.01692)$ & $(0.01607)$ & $(0.01751)$ \\
\hline \multirow[t]{2}{*}{ Central SOE developer } & -0.01655 & -0.01624 & -0.01554 \\
\hline & $(0.01142)$ & $(0.01126)$ & $(0.01128)$ \\
\hline \multirow[t]{2}{*}{ Local SOE developer } & $0.03405 *$ & $0.03259 *$ & $0.03183 *$ \\
\hline & $(0.02011)$ & $(0.01885)$ & $(0.01890)$ \\
\hline Foreign manufacturer* & & & $-0.13107 * *$ \\
\hline cooperating experience & & & $(0.06000)$ \\
\hline Province fixed effects & Yes & Yes & Yes \\
\hline Year fixed effects & No & Yes & Yes \\
\hline \multirow{2}{*}{ Constant } & $-0.18107^{* *}$ & -0.13652 & -0.13711 \\
\hline & $(0.08414)$ & $(0.09879)$ & $(0.09880)$ \\
\hline Observations & 486 & 486 & 486 \\
\hline R-squared & 0.660 & 0.685 & 0.687 \\
\hline
\end{tabular}

Note: Robust standard errors in parentheses, ${ }^{* * *} \mathrm{p}<0.01,{ }^{* *} \mathrm{p}<0.05{ }^{*} \mathrm{p}<0.1$. Knowledge spillover from the industry is omitted in both model (2) and (3) with year fixed effects because the sum of all the four experience variables equals to the total industry-wide installed capacity in a given year, which is correlated with the year dummies. 


\section{Table 7: Effects of Collaborating Experience on Unit Capital Cost and Capacity Factor}

\begin{tabular}{|c|c|c|c|c|c|c|}
\hline Dependent Variables & $\begin{array}{c}(1) \\
\ln (\text { unit cost) }\end{array}$ & $\begin{array}{c}(2) \\
\ln (\text { unit cost) }\end{array}$ & $\begin{array}{c}\text { (3) } \\
\ln (\text { unit capital } \\
\text { cost) }\end{array}$ & $\begin{array}{c}\text { (4) } \\
\ln (\text { unit capital } \\
\text { cost) }\end{array}$ & $\begin{array}{c}(5) \\
\ln (\text { capacity } \\
\text { factor) }\end{array}$ & $\begin{array}{c}(6) \\
\ln (\text { capacity } \\
\text { factor) }\end{array}$ \\
\hline $\begin{array}{l}\text { Knowledge stock of } \\
\text { manufacturer }\end{array}$ & $\begin{array}{c}-0.00029 * * \\
(0.00013)\end{array}$ & $\begin{array}{l}-0.00025^{*} \\
(0.00013)\end{array}$ & $\begin{array}{c}-0.00031 * \\
(0.00018)\end{array}$ & $\begin{array}{l}-0.00027 \\
(0.00017)\end{array}$ & $\begin{array}{c}0.00032 * * \\
(0.00013)\end{array}$ & $\begin{array}{c}0.00031 * * \\
(0.00013)\end{array}$ \\
\hline $\begin{array}{l}\text { Manufacturer's experience } \\
\text { alone (GW) }\end{array}$ & $\begin{array}{l}-0.00211 \\
(0.00572)\end{array}$ & $\begin{array}{l}-0.00216 \\
(0.00571)\end{array}$ & $\begin{array}{l}-0.00768 \\
(0.00704)\end{array}$ & $\begin{array}{l}-0.00772 \\
(0.00703)\end{array}$ & $\begin{array}{c}0.00409 \\
(0.00561)\end{array}$ & $\begin{array}{c}0.00410 \\
(0.00561)\end{array}$ \\
\hline Developer's experience in & $-0.02333 * * *$ & $-0.02230 * * *$ & $-0.03393 * * *$ & $-0.03304 * * *$ & 0.01073* & $0.01046 *$ \\
\hline CDM projects alone (GW) & $(0.00658)$ & $(0.00655)$ & $(0.00800)$ & $(0.00798)$ & $(0.00573)$ & $(0.00574)$ \\
\hline $\begin{array}{l}\text { Cooperating experience in } \\
\text { CDM (GW) }\end{array}$ & $\begin{array}{c}-0.04149 * * \\
(0.01874)\end{array}$ & $\begin{array}{c}-0.03971^{* *} \\
(0.01876)\end{array}$ & $\begin{array}{c}-0.05406^{* *} \\
(0.02299)\end{array}$ & $\begin{array}{c}-0.05252^{* *} \\
(0.02314)\end{array}$ & $\begin{array}{c}0.00648 \\
(0.01987)\end{array}$ & $\begin{array}{c}0.00601 \\
(0.01999)\end{array}$ \\
\hline Turbine size (MW) & $\begin{array}{c}0.01068 \\
(0.01481)\end{array}$ & $\begin{array}{c}0.00929 \\
(0.01493)\end{array}$ & $\begin{array}{l}0.03342^{*} \\
(0.01817)\end{array}$ & $\begin{array}{l}0.03221^{*} \\
(0.01825)\end{array}$ & $\begin{array}{c}0.05609 * * * \\
(0.01113)\end{array}$ & $\begin{array}{c}0.05646 * * * \\
(0.01120)\end{array}$ \\
\hline Project size (GW) & $\begin{array}{c}-0.34063 * * * \\
(0.12296)\end{array}$ & $\begin{array}{c}-0.33709 * * * \\
(0.12246)\end{array}$ & $\begin{array}{c}-0.34582^{* * * *} \\
(0.13293)\end{array}$ & $\begin{array}{c}-0.34276^{* *} \\
(0.13291)\end{array}$ & $\begin{array}{l}0.13304^{*} \\
(0.07367)\end{array}$ & $\begin{array}{l}0.13211^{*} \\
(0.07360)\end{array}$ \\
\hline Wind category 1 & $\begin{array}{c}-0.14092 * * * \\
(0.02805)\end{array}$ & $\begin{array}{c}-0.14541 * * * \\
(0.02850)\end{array}$ & $\begin{array}{c}-0.21581^{* * * *} \\
(0.02739)\end{array}$ & $\begin{array}{c}-0.21969 * * * \\
(0.02766)\end{array}$ & $\begin{array}{c}0.13652 * * * \\
(0.03066)\end{array}$ & $\begin{array}{c}0.13770 * * * \\
(0.03059)\end{array}$ \\
\hline Wind category 2 & $\begin{array}{c}-0.09387 * * * \\
(0.02688)\end{array}$ & $\begin{array}{c}-0.09348 * * * \\
(0.02706)\end{array}$ & $\begin{array}{c}-0.16919 * * * \\
(0.02500)\end{array}$ & $\begin{array}{c}-0.16885 * * * \\
(0.02479)\end{array}$ & $\begin{array}{c}0.09923 * * * \\
(0.03028)\end{array}$ & $\begin{array}{c}0.09913^{* * * *} \\
(0.03016)\end{array}$ \\
\hline Wind category 3 & $\begin{array}{l}-0.01251 \\
(0.01974)\end{array}$ & $\begin{array}{l}-0.01419 \\
(0.01983)\end{array}$ & $\begin{array}{l}-0.02476 \\
(0.01851)\end{array}$ & $\begin{array}{l}-0.02621 \\
(0.01852)\end{array}$ & $\begin{array}{l}-0.00723 \\
(0.01576)\end{array}$ & $\begin{array}{l}-0.00679 \\
(0.01576)\end{array}$ \\
\hline Foreign manufacturer & $\begin{array}{l}0.03097^{*} \\
(0.01607)\end{array}$ & $\begin{array}{c}0.03969 * * \\
(0.01751)\end{array}$ & $\begin{array}{l}0.03535^{*} \\
(0.01951)\end{array}$ & $\begin{array}{r}0.04288 * * \\
(0.02138)\end{array}$ & $\begin{array}{c}0.00442 \\
(0.01530)\end{array}$ & $\begin{array}{c}0.00214 \\
(0.01611)\end{array}$ \\
\hline Central SOE developer & $\begin{array}{l}-0.01624 \\
(0.01126)\end{array}$ & $\begin{array}{l}-0.01554 \\
(0.01128)\end{array}$ & $\begin{array}{l}-0.00684 \\
(0.01453)\end{array}$ & $\begin{array}{l}-0.00624 \\
(0.01453)\end{array}$ & $\begin{array}{c}0.00514 \\
(0.01040)\end{array}$ & $\begin{array}{c}0.00495 \\
(0.01041)\end{array}$ \\
\hline Local SOE developer & $\begin{array}{l}0.03259 * \\
(0.01885)\end{array}$ & $\begin{array}{l}0.03183^{*} \\
(0.01890)\end{array}$ & $\begin{array}{l}0.05485^{* *} \\
(0.02443)\end{array}$ & $\begin{array}{l}0.05419 * * \\
(0.02451)\end{array}$ & $\begin{array}{l}-0.02825 \\
(0.01902)\end{array}$ & $\begin{array}{l}-0.02805 \\
(0.01909)\end{array}$ \\
\hline $\begin{array}{l}\text { Foreign manufacturer* } \\
\text { cooperating experience }\end{array}$ & & $\begin{array}{c}-0.13107^{* *} \\
(0.06000)\end{array}$ & & $\begin{array}{l}-0.11329 \\
(0.08382)\end{array}$ & & $\begin{array}{c}0.03435 \\
(0.05582)\end{array}$ \\
\hline Province fixed effects & Yes & Yes & Yes & Yes & Yes & Yes \\
\hline Year fixed effects & Yes & Yes & Yes & Yes & Yes & Yes \\
\hline Constant & $\begin{array}{l}-0.13652 \\
(0.09879)\end{array}$ & $\begin{array}{l}-0.13711 \\
(0.09880)\end{array}$ & $\begin{array}{c}-0.45304 * * * \\
(0.09859)\end{array}$ & $\begin{array}{c}-0.45354 * * * \\
(0.09857)\end{array}$ & $\begin{array}{c}-1.64860 * * * \\
(0.07751)\end{array}$ & $\begin{array}{c}-1.64845^{* * *} \\
(0.07754)\end{array}$ \\
\hline & 486 & 486 & 486 & 486 & 486 & 486 \\
\hline R-squared & 0.685 & 0.687 & 0.607 & 0.608 & 0.601 & 0.601 \\
\hline
\end{tabular}

Note: Robust standard errors in parentheses, ${ }^{* * *} \mathrm{p}<0.01,{ }^{* *} \mathrm{p}<0.05$, ${ }^{*} \mathrm{p}<0.1$. Knowledge spillover from the industry is omitted in all the models because the sum of all the four experience variables equals to the total industry-wide installed capacity in a given year, which is correlated with the year dummies. 
Figure 1: Share of Annual Incremental CDM Wind Installed Capacity in China's Wind Power

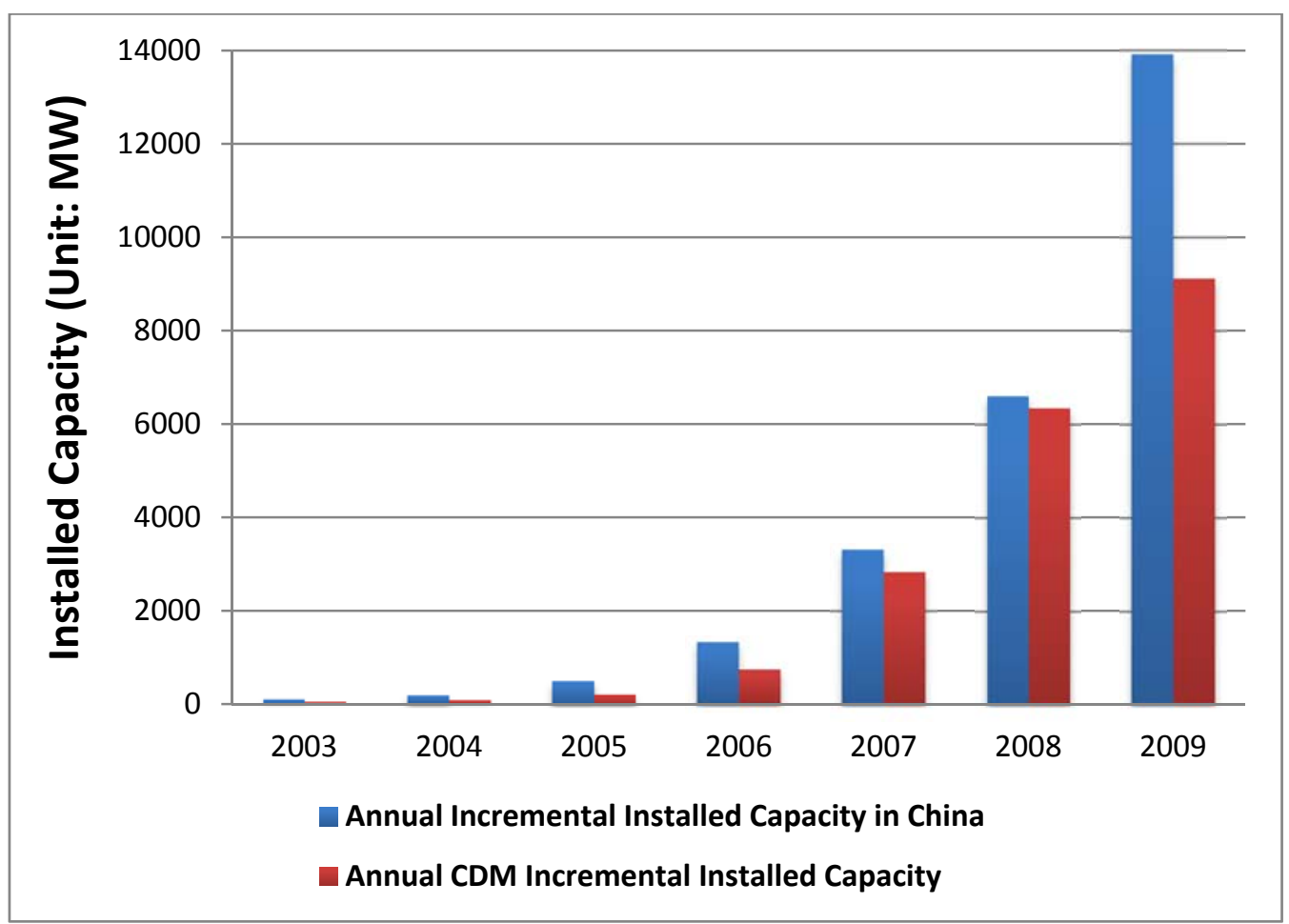

Notes: Annual total installed capacity data comes from the CWEA's annual reports on China's wind power. CDM installed capacity data is collected from the CDM Pipeline and CDM project design documents. Due to the CDM registration process, the incremental installed capacity from CDM projects in 2009 is incomplete. Thus, the CDM share shown for 2009 may be lower than the actual share. 
Figure 2: A Standard CDM Project Cycle

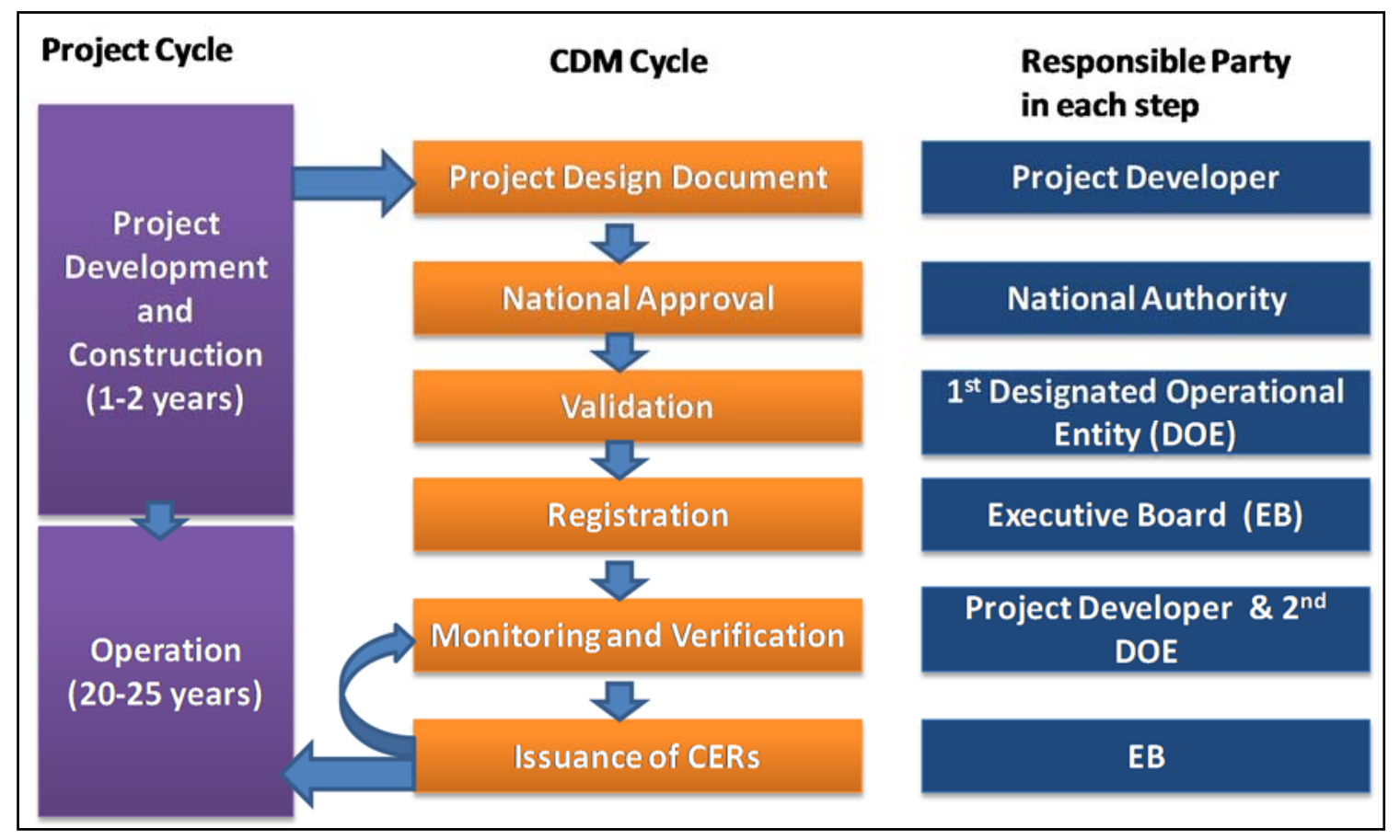

Figure 3: The Trends of Project Unit Costs from 2004 to 2009

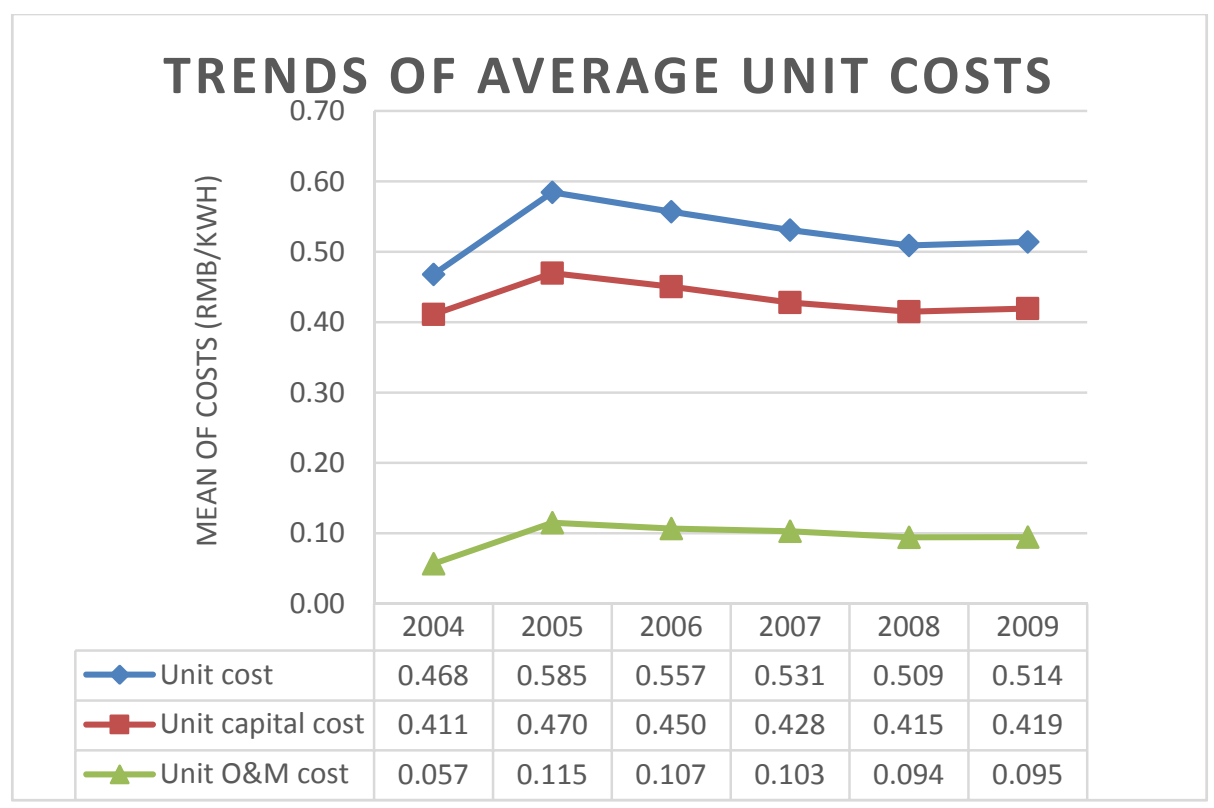


Figure 4: Trend of Capacity Factors in Each Year

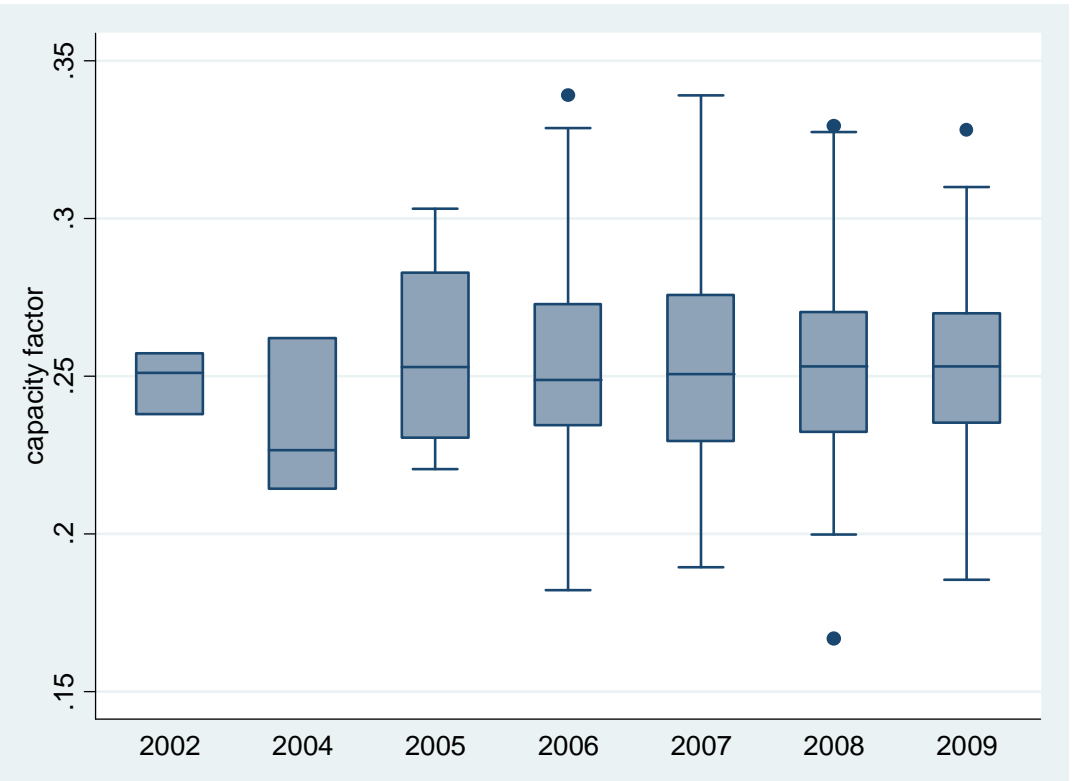

Notes: The horizontal line in the middle of each box represents the median, while the box represents the range between the first and third quantiles. The upper and lower horizontal lines represent the most extreme values which within Q3+1.5(Q3-Q1) and Q1-1.5*(Q3-Q1). Dots represent outlier observations. 


\section{Appendix}

Table A1 Effects of Aggregate Level Experience on Unit Capital Cost and Capacity Factor

\begin{tabular}{|c|c|c|c|}
\hline Dependent Variables & $\begin{array}{c}(1) \\
\ln (\text { unit cost) }\end{array}$ & $\begin{array}{c}\text { (2) } \\
\ln (\text { unit capital cost) }\end{array}$ & $\begin{array}{c}\text { (3) } \\
\ln \text { (capacity factor) }\end{array}$ \\
\hline $\begin{array}{l}\text { Knowledge stock } \\
\text { of manufacturer }\end{array}$ & $\begin{array}{c}-0.00037 * * \\
(0.00015)\end{array}$ & $\begin{array}{c}-0.00042 * * \\
(0.00021)\end{array}$ & $\begin{array}{c}0.00035 * * * \\
(0.00013)\end{array}$ \\
\hline Province level experience & 0.00457 & -0.00296 & -0.00951 \\
\hline$(\mathrm{GW})$ & $(0.00723)$ & $(0.00888)$ & $(0.00625)$ \\
\hline Turbine size & 0.01149 & $0.03683 * *$ & $0.05582 * * *$ \\
\hline$(\mathrm{MW})$ & $(0.01503)$ & $(0.01858)$ & $(0.01130)$ \\
\hline Project size & $-0.32164 * * *$ & $-0.33291 * *$ & 0.11527 \\
\hline$(\mathrm{GW})$ & $(0.12414)$ & $(0.13833)$ & $(0.07268)$ \\
\hline Wind category 1 & $\begin{array}{c}-0.13557 * * * \\
(0.02839)\end{array}$ & $\begin{array}{c}-0.20836 * * * \\
(0.02820)\end{array}$ & $\begin{array}{c}0.13501 * * * \\
(0.03142)\end{array}$ \\
\hline Wind category 2 & $\begin{array}{c}-0.09914^{* * *} \\
(0.02696)\end{array}$ & $\begin{array}{c}-0.17539 * * * \\
(0.02607)\end{array}$ & $\begin{array}{c}0.10257 * * * \\
(0.03108)\end{array}$ \\
\hline Wind category 3 & $\begin{array}{l}-0.00948 \\
(0.02184)\end{array}$ & $\begin{array}{l}-0.02110 \\
(0.02033)\end{array}$ & $\begin{array}{l}-0.00728 \\
(0.01626)\end{array}$ \\
\hline Foreign manufacturer & $\begin{array}{c}0.03793 * * \\
(0.01609)\end{array}$ & $\begin{array}{l}0.04489 * * \\
(0.01961)\end{array}$ & $\begin{array}{c}0.00130 \\
(0.01504)\end{array}$ \\
\hline Central SOE developer & $\begin{array}{c}-0.04186 * * * \\
(0.01008)\end{array}$ & $\begin{array}{c}-0.08436 * * * \\
(0.02092)\end{array}$ & $\begin{array}{l}0.01498 * \\
(0.00891)\end{array}$ \\
\hline Local SOE developer & $\begin{array}{c}0.02352 \\
(0.01862)\end{array}$ & $\begin{array}{l}-0.04343 * \\
(0.02403)\end{array}$ & $\begin{array}{l}-0.02511 \\
(0.01863)\end{array}$ \\
\hline Province fixed effects & Yes & Yes & Yes \\
\hline Year fixed effects & Yes & Yes & Yes \\
\hline Constant & $\begin{array}{l}-0.12832 \\
(0.09902)\end{array}$ & $\begin{array}{c}-0.41078 * * * \\
(0.09795)\end{array}$ & $\begin{array}{c}-1.65687^{* * * *} \\
(0.07692)\end{array}$ \\
\hline Observations & 486 & 486 & 486 \\
\hline R-squared & 0.668 & 0.579 & 0.599 \\
\hline
\end{tabular}

Note: Robust standard errors in parentheses, ${ }^{* * *} \mathrm{p}<0.01,{ }^{* *} \mathrm{p}<0.05$, ${ }^{*} \mathrm{p}<0.1$. Industrial level experience omitted in all models because the sum of provincial experience and industrial experience equals to the total industrywide capacity in a given year, which is correlated with the year dummies. 
Table A2 Learning-by-doing and Spillover Effects on Unit Capital Cost and Capacity Factor

\begin{tabular}{|c|c|c|c|}
\hline Dependent Variables & $\begin{array}{c}\text { (1) } \\
\ln (\text { unit cost) }\end{array}$ & $\begin{array}{c}(2) \\
\ln \text { (unit capital cost) }\end{array}$ & $\begin{array}{c}(3) \\
\ln (\text { capacity factor) }\end{array}$ \\
\hline $\begin{array}{l}\text { Knowledge stock of } \\
\text { manufacturer }\end{array}$ & $\begin{array}{c}-0.00029 * * \\
(0.00013)\end{array}$ & $\begin{array}{l}-0.00031 * \\
(0.00018)\end{array}$ & $\begin{array}{l}0.00031 * * \\
(0.00013)\end{array}$ \\
\hline Manufacturer' experience & -0.01816 & -0.02013 & 0.00547 \\
\hline$(\mathrm{GW})$ & $(0.02285)$ & $(0.02752)$ & $(0.00540)$ \\
\hline Developer's experience in & $-0.03938 *$ & $-0.04638 *$ & $0.01178 * *$ \\
\hline CDM projects (GW) & $(0.02017)$ & $(0.02475)$ & (0.00539) \\
\hline Spillover from the & -0.01605 & -0.01245 & 0.00221 \\
\hline industry (GW) & $(0.02444)$ & $(0.02942)$ & $(0.00464)$ \\
\hline Turbine size (MW) & $\begin{array}{c}0.01068 \\
(0.01481)\end{array}$ & $\begin{array}{l}0.03342^{*} \\
(0.01817)\end{array}$ & $\begin{array}{c}0.05580^{* * * *} \\
(0.01106)\end{array}$ \\
\hline Project size (GW) & $\begin{array}{c}-0.34063 * * * \\
(0.12296)\end{array}$ & $\begin{array}{c}-0.34582 * * * \\
(0.13293)\end{array}$ & $\begin{array}{l}0.13640 * \\
(0.07297)\end{array}$ \\
\hline Wind category 1 & $\begin{array}{c}-0.14092 * * * \\
(0.02805)\end{array}$ & $\begin{array}{c}-0.21581 * * * \\
(0.02739)\end{array}$ & $\begin{array}{c}0.13736 * * * \\
(0.02929)\end{array}$ \\
\hline Wind category 2 & $\begin{array}{c}-0.09387 * * * \\
(0.02688)\end{array}$ & $\begin{array}{c}-0.16919 * * * \\
(0.02500)\end{array}$ & $\begin{array}{c}0.09945 * * * \\
(0.02909)\end{array}$ \\
\hline Wind category 3 & $\begin{array}{l}-0.01251 \\
(0.01974)\end{array}$ & $\begin{array}{l}-0.02476 \\
(0.01851)\end{array}$ & $\begin{array}{l}-0.00532 \\
(0.01526)\end{array}$ \\
\hline Foreign manufacturer & $\begin{array}{l}0.03097 * \\
(0.01607)\end{array}$ & $\begin{array}{l}0.03535 * \\
(0.01951)\end{array}$ & $\begin{array}{c}0.00438 \\
(0.01508)\end{array}$ \\
\hline Central SOE developer & $\begin{array}{l}-0.01624 \\
(0.01126)\end{array}$ & $\begin{array}{l}-0.00684 \\
(0.01453)\end{array}$ & $\begin{array}{c}0.00486 \\
(0.01019)\end{array}$ \\
\hline Local SOE developer & $\begin{array}{l}0.03259 * \\
(0.01885)\end{array}$ & $\begin{array}{l}0.05485 * * \\
(0.02443)\end{array}$ & $\begin{array}{l}-0.02713 \\
(0.01889)\end{array}$ \\
\hline Province fixed effects & Yes & Yes & Yes \\
\hline Year fixed effects & Yes & Yes & Yes \\
\hline Constant & $\begin{array}{c}-0.45777 * * * \\
(0.10299)\end{array}$ & $\begin{array}{c}-0.64313 * * * \\
(0.10847)\end{array}$ & $\begin{array}{c}-1.62209 * * * \\
(0.07938)\end{array}$ \\
\hline Observations & 486 & 486 & 486 \\
\hline R-squared & 0.684 & 0.607 & 0.599 \\
\hline
\end{tabular}

Note: Robust standard errors in parentheses, ${ }^{* * *} \mathrm{p}<0.01,{ }^{* *} \mathrm{p}<0.05,{ }^{*} \mathrm{p}<0.1$. 